\title{
Synthesis and Biological Evaluation of Honokiol Derivatives Bearing 3-((5-phenyl-1,3,4-oxadiazol-2-yl)methyl)oxazol- 2(3H)-ones as Potential Viral Entry Inhibitors against SARS-CoV-2
}

\author{
Yong Guo ${ }^{1,2,+}$, Jie-Ru Meng ${ }^{1,+}$, Jia-Zheng Liu ${ }^{1}$, Ting $X u^{1}$, Zhi-Yuan Zheng ${ }^{1}$, Zhi-Hong Jiang ${ }^{1}$ (D) \\ and Li-Ping Bai ${ }^{1, *}$
}

Citation: Guo, Y.; Meng, J.-R.; Liu, J.-Z.; Xu, T.; Zheng, Z.-Y.; Jiang, Z.-H.; Bai, L.-P. Synthesis and Biological Evaluation of Honokiol Derivatives Bearing 3-((5-phenyl-1,3,4-oxadiazol2-yl)methyl)oxazol-2(3H)-ones as Potential Viral Entry Inhibitors against SARS-CoV-2. Pharmaceuticals 2021, 14, 885. https://doi.org/ $10.3390 /$ ph14090885

Academic Editor: Jean Jacques Vanden Eynde

Received: 16 August 2021

Accepted: 29 August 2021

Published: 31 August 2021

Publisher's Note: MDPI stays neutral with regard to jurisdictional claims in published maps and institutional affiliations.

Copyright: (c) 2021 by the authors. Licensee MDPI, Basel, Switzerland. This article is an open access article distributed under the terms and conditions of the Creative Commons Attribution (CC BY) license (https:// creativecommons.org/licenses/by/ $4.0 /)$.
1 State Key Laboratory of Quality Research in Chinese Medicine, Macau Institute for Applied Research in Medicine and Health, Guangdong-Hong Kong-Macao Joint Laboratory of Respiratory Infectious Disease, Macau University of Science and Technology, Taipa, Macau 999078, China; yguo@must.edu.mo (Y.G.); 1909853gct20002@student.must.edu.mo (J.-R.M.); 2009853DCT20001@student.must.edu.mo (J.-Z.L.); 1909853ect30003@student.must.edu.mo (T.X.); 1709853ect30001@student.must.edu.mo (Z.-Y.Z.); zhjiang@must.edu.mo (Z.-H.J.)

2 School of Pharmaceutical Sciences, Zhengzhou University, Zhengzhou 450001, China

* Correspondence: lpbai@must.edu.mo; Tel.: +853-8897-2403

$\dagger \quad$ These authors contributed equally.

\begin{abstract}
The 2019 coronavirus disease (COVID-19) caused by SARS-CoV-2 virus infection has posed a serious danger to global health and the economy. However, SARS-CoV-2 medications that are specific and effective are still being developed. Honokiol is a bioactive component from Magnoliae officinalis Cortex with damp-drying effect. To develop new potent antiviral molecules, a series of novel honokiol analogues were synthesized by introducing various 3-((5-phenyl-1,3,4oxadiazol-2-yl)methyl)oxazol-2(3H)-ones to its molecule. In a SARS-CoV-2 pseudovirus model, all honokiol derivatives were examined for their antiviral entry activities. As a result, $\mathbf{6 a}$ and $\mathbf{6 p}$ demonstrated antiviral entry effect with $\mathrm{IC}_{50}$ values of 29.23 and $9.82 \mu \mathrm{M}$, respectively. However, the parental honokiol had a very weak antiviral activity with an $\mathrm{IC}_{50}$ value more than $50 \mu \mathrm{M}$. A biolayer interfero-metry (BLI) binding assay and molecular docking study revealed that $6 \mathbf{p}$ binds to human ACE2 protein with higher binding affinity and lower binding energy than the parental honokiol. A competitive ELISA assay confirmed the inhibitory effect of $6 p$ on SARS-CoV-2 spike RBD's binding with ACE2. Importantly, $6 \mathbf{a}$ and $\mathbf{6 p}\left(\mathrm{TC}_{50}>100 \mu \mathrm{M}\right)$ also had higher biological safety for host cells than honokiol ( $\mathrm{TC}_{50}$ of $48.23 \mu \mathrm{M}$ ). This research may contribute to the discovery of potential viral entrance inhibitors for the SARS-CoV-2 virus, although 6 p's antiviral efficacy needs to be validated on SARS-CoV-2 viral strains in a biosafety level 3 facility.
\end{abstract}

Keywords: honokiol analogues; viral entry inhibitors; SARS-CoV-2; COVID-19; ACE2 blocker

\section{Introduction}

As of June 2021, more than 170 million individuals had been infected worldwide since the outbreak of a novel coronavirus-associated acute respiratory disease (COVID-19) in December of 2019. Nowadays there are still no specific medications for COVID-19 patients, except for symptomatic treatment. SARS-CoV-2 necessitates the creation of specific and effective medications. ACE2, a receptor located on the outer surface of a wide variety of host cells, is the primary target to which the SARS-CoV-2 spike attaches. ACE2-targeted molecules, such as oroxylin A [1], peptide AYp28 [2], doxepin [3], and dexamethasone [4], have been reported to block SARS-CoV-2 spike RBD's interactions with ACE2, and thus exert antiviral entry effects on SARS-CoV-2. Therefore, targeting ACE2 with organic molecules is an alternative strategy for the discovery of effective antiviral 
drugs to prevent or combat SARS-CoV-2. Magnoliae officinalis Cortex (also known as "Hou

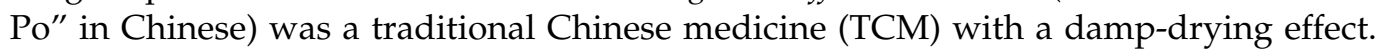
It was a major herb in a number of TCM prescriptions or Chinese patent medications, including Hua-Shi-Bai-Du formulation [5], Dayuan Decoction [6], and Huoxiang Zhengqi Dropping Pills [7] which were useful and effective in treating COVID-19 in clinics. As a main and bioactive component in this TCM, honokiol has been shown to prevent viral entry into host cells, hence fighting viruses including hepatitis $\mathrm{C}$ virus (HCV) [8] and dengue fever virus (DENV) [9]. Therefore, honokiol was considered as an ideal molecule for structural modification in order to find new antiviral entry inhibitors for SARS-CoV-2.

An ideal antiviral molecule is required to possess low cytotoxicity to host cells and high antiviral efficacy. In our previous studies $[10,11]$, it was found that honokiol was toxic to both cancerous and non-cancer cells, probably due to the presence of two phenolic hydroxyl groups. The introduction of 1,3,4-oxadiazole-linked phenyls to honokiol (9a-9o in the literature [10]) could reduce cytotoxic effects on non-cancer cells. Additionally, compounds containing 1,3,4-oxadiazole moiety have recently been reported to exhibit good antiviral activity against SARS-CoV-2 [12,13]. Our preliminary computational study also exhibited that the oxadiazole linker could form conventional hydrogen bonding interactions with active sites in ACE2 protein. Based on the above considerations, 1,3,4-oxadiazole-linked phenyls were employed to modify the molecule of honokiol with the design of oxazolone group to block phenolic hydroxyl groups. Herein, a series of honokiol analogues were synthesized by introducing various 3-((5-phenyl-1,3,4-oxadiazol-2-yl)methyl)oxazol-2(3H)ones into its molecule. Their antiviral entrance properties were tested in a SARS-CoV-2 pseudovirus model based on the viral spike protein by using a lentiviral system that included a luciferase reporter gene for quantifying spike and ACE2-mediated virus entry in a biosafety level 2 (BSL-2) facility [14-21]. The in vitro binding affinities of antiviral derivatives were subsequently examined with both SARS-CoV-2 spike RBD and human ACE2 proteins by BLI binding assay [22,23]. Subsequently, a molecular docking study was also employed to further predict their active binding sites in SARS-CoV-2 human ACE2 receptor. Finally, a competitive ELISA assay was carried out to investigate the inhibitory effect of antiviral analogues on the binding interaction of spike RBD with ACE2. This research could lead to potential SARS-CoV-2 viral entrance inhibitors.

\section{Results and Discussion}

\subsection{Chemistry}

As shown in Scheme 1, various substituted benzoic acids (a-p) were used as starting materials to firstly prepare key intermediates 2-chloromethyl-5-substituted phenyl1,3,4-oxadiazoles 5a-p through four steps of esterification, hydrazinolysis, amidation, and cyclization according to the reported procedures [11]. Secondly, the nitro group was successfully introduced at the ortho position of hydroxyl groups of the honokiol via nitration reaction to obtain 3,5'-dinitrohonokiol (2), which was then reduced by $\mathrm{SnCl}_{2}$ to produce 3,5'diaminohonokiol (3). Subsequently, 3,5'-diaminohonokiol (3) was reacted with urea at 140 ${ }^{\circ} \mathrm{C}$ to obtain another key cyclized product 4 [24]. Finally, a series of novel honokiol derivatives 6a-p containing various 3-((5-phenyl-1,3,4-oxadiazol-2-yl)methyl)oxazol-2(3H)-ones were smoothly prepared by reacting compound 4 with the corresponding 2-chloromethyl5-substituted phenyl-1,3,4-oxadiazoles 5a-p in the presence of $\mathrm{K}_{2} \mathrm{CO}_{3}$ and $\mathrm{KI}$ [25]. All honokiol derivatives 6a-p were characterized by IR, HRMS and ${ }^{1} \mathrm{H} /{ }^{13} \mathrm{C}$ NMR. The purities of analogues $6 \mathbf{a}-\mathbf{p}$ were determined more than $95 \%$ by HPLC analysis before a biological evaluation. 

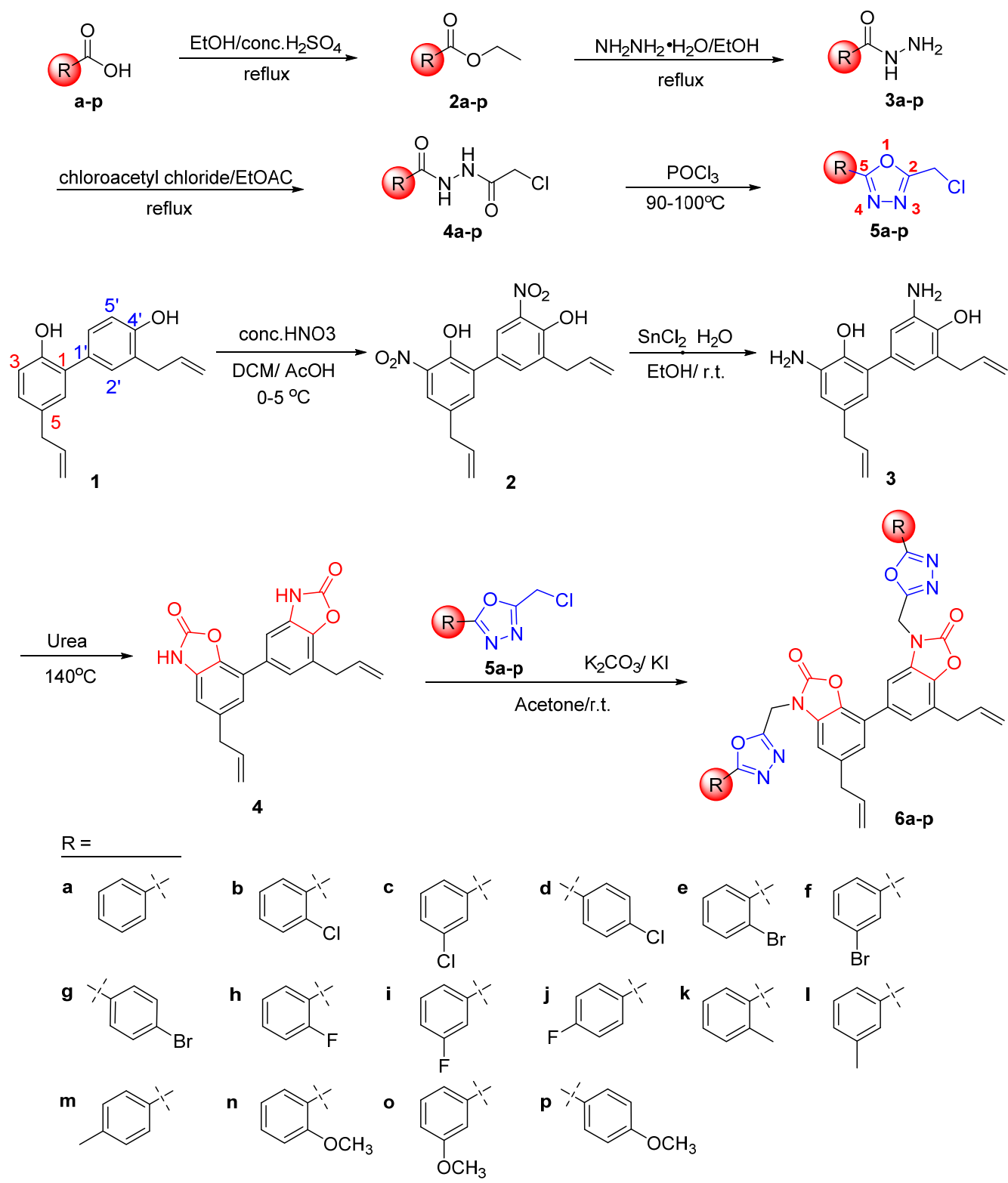

Scheme 1. Synthetic routes of honokiol derivatives 6a-p bearing 3-((5-phenyl-1,3,4-oxadiazol-2-yl)methyl)oxazol-2(3H)ones.

\subsection{Biological Evaluation}

2.2.1. Antiviral Activities of Honokiol Analogues 6a-p against the Entry of SARS-CoV-2 Pseudovirus into Host Cells

In our BSL-2 facility, SARS-CoV-2 spike pseudotyped viruses with luciferase reporter were constructed to infect HEK-293T-ACE2 ${ }^{\text {h }}$ cells that produce high levels of human ACE2 (angiotensin-converting enzyme 2). This experimental model could help researchers find potential antiviral compounds that prevent SARS-CoV-2 from infecting host cells overexpressing ACE2 receptor. Initially, the maximum nontoxic concentration $\left(\mathrm{CC}_{0}\right)$ values of honokiol derivatives 6a-p were determined against the host cell of HEK-293T-ACE2 ${ }^{\text {h }}$ by MTT (Table 1). Subsequently, the antiviral entry activities of compounds were evaluated under their doses of no higher than CC $_{0}$ values. HEK-293T-ACE2 ${ }^{\mathrm{h}}$ cells infected only with SARS-CoV-2 spike pseudovirus were considered as controls, and the value of luciferase luminescence of the control was defined as 100\%. A SARS-CoV-2 antibody was utilized as a positive viral entry inhibitor. As shown in Figure 1 and Table 1, the positive inhibitor suppressed the entry of the pseudovirus with an $\mathrm{IC}_{50}$ value of $0.035 \mu \mathrm{M}$. Compounds $6 \mathbf{a}$, 
6h, and $6 \mathbf{p}$ demonstrated $\mathrm{IC}_{50}$ values of $29.23,61.58$, and $9.82 \mu \mathrm{M}$ against the pseudovirus entry, respectively. However, the parental honokiol only exhibited very weak inhibitory effect on pseudovirus entry with $\mathrm{IC}_{50}$ value more than $50 \mu \mathrm{M}$. The $\mathrm{IC}_{50}$ values of all the other analogues $\mathbf{6 b}-\mathbf{g}$, $\mathbf{6 i - o}$ were all more than their $\mathrm{CC}_{0}$ values. With $\mathrm{TC}_{50}$ values greater than $100 \mu \mathrm{M}, \mathbf{6 a}, \mathbf{6 h}$, and $\mathbf{6 p}$ had a less cytotoxic effect on HEK-293T-ACE2 ${ }^{\mathrm{h}}$ host cells than honokiol $\left(\mathrm{TC}_{50}\right.$ of $\left.48.23 \mu \mathrm{M}\right)$. Taken together, $\mathbf{6} \mathbf{p}$ had the most potent antiviral entry effect on the pseudovirus with a selectivity index (SI) higher than 10.18 among all honokiol derivatives.

Table 1. Antiviral properties of honokiol derivatives 6a-p against the entry of SARS-CoV-2 spike pseudovirus into HEK-293T-ACE2 ${ }^{\mathrm{h}}$ cells.

\begin{tabular}{|c|c|c|c|c|}
\hline Compounds & $\mathrm{CC}_{0}{ }^{1}(\mu \mathrm{M})$ & $\mathrm{TC}_{50}{ }^{2}(\mu \mathrm{M})$ & $\mathrm{IC}_{50}{ }^{3}(\mu \mathrm{M})$ & $\mathrm{SI}^{4}$ \\
\hline $6 a$ & $>100$ & $>100$ & $29.23 \pm 0.71$ & $>3.42$ \\
\hline $6 b$ & $>100$ & $>100$ & $>100$ & ND \\
\hline $6 c$ & $>100$ & $>100$ & $>100$ & ND \\
\hline $6 d$ & 50 & ND & $>50$ & ND \\
\hline $6 e$ & $>100$ & $>100$ & $>100$ & ND \\
\hline $6 f$ & 50 & ND & $>50$ & ND \\
\hline $6 \mathrm{~g}$ & 50 & ND & $>50$ & ND \\
\hline $6 \mathrm{~h}$ & $>100$ & $>100$ & $61.58 \pm 1.21$ & $>1.62$ \\
\hline $6 i$ & $>100$ & $>100$ & $>100$ & ND \\
\hline $6 j$ & 50 & ND & $>50$ & ND \\
\hline $6 \mathrm{k}$ & $>100$ & $>100$ & $>100$ & ND \\
\hline 61 & $>100$ & $>100$ & $>100$ & ND \\
\hline $6 \mathrm{~m}$ & 50 & ND & $>50$ & ND \\
\hline $6 n$ & 50 & ND & $>50$ & ND \\
\hline 60 & $>100$ & $>100$ & $>100$ & ND \\
\hline $6 p$ & $>100$ & $>100$ & $9.82 \pm 1.16$ & $>10.18$ \\
\hline honokiol & 50 & $48.23 \pm 1.19$ & $>50$ & ND \\
\hline Antibody inhibitor 5 & 0.10 & ND & $0.035 \pm 0.001$ & ND \\
\hline
\end{tabular}

${ }^{1} \mathrm{CC}_{0}$ means the maximum nontoxic concentration of compounds for $4 \mathrm{~h}$ incubation with cells; ${ }^{2} \mathrm{TC}_{50}$ is the necessary concentration that caused $50 \%$ host cells' death for $48 \mathrm{~h}$ treatment; ${ }^{3} \mathrm{IC}_{50}$ stands for the compounds' concentration that inhibited $50 \%$ viral entry into host cells. ${ }^{4}$ SI means selectivity index that measures compounds' window between cytotoxicity and antiviral activity by dividing the $\mathrm{TC}_{50}$ value into the $\mathrm{IC}_{50}$ value $\left(\mathrm{TC}_{50} / \mathrm{IC}_{50}\right){ }^{5}$ SARS-CoV-2 antibody was used as a positive viral entry inhibitor; ND means not determined. All the data are expressed as means \pm standard deviation (SD) from three independent experiments.

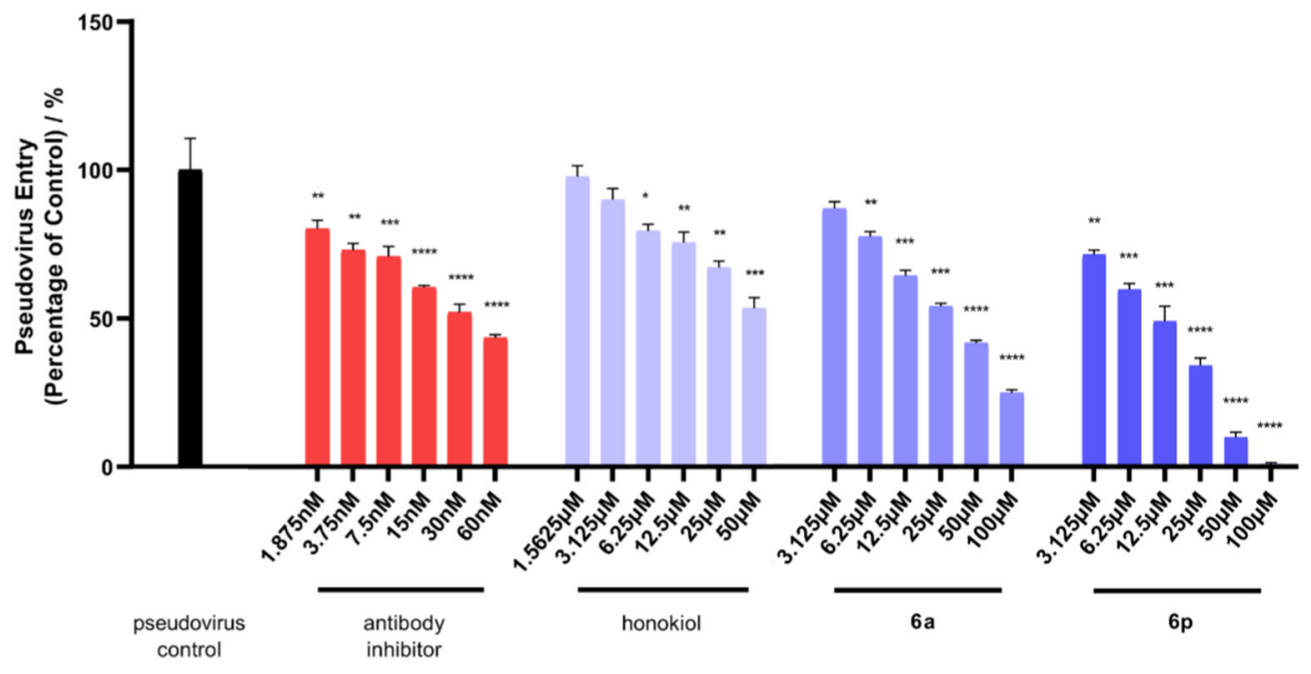

Figure 1. Effect of honokiol, representative $6 \mathbf{a}$ and $\mathbf{6 p}$ on the entrance of SARS-CoV-2 pseudovirus into HEK-293T-ACE2 ${ }^{\text {h }}$ cells. The luciferase luminescence value of the pseudovirus control was defined as $100 \%$. The values of luminescence of either antibody inhibitor-treated or compound-treated groups were normalized accordingly. Results were expressed as mean \pm standard error $(\mathrm{n}=4){ }^{*} p<0.05,{ }^{* *} p<0.01,{ }^{* * *} p<0.001,{ }^{* * * *} p<0.0001$ compared with pseudovirus control group. The experiments were repeated at least three times. 


\subsubsection{Biolayer Interferometry (BLI) Binding Assay}

The attachment of the spike receptor binding domain (RBD) to the ACE2 receptor is the first key and critical step in the SARS-CoV-2 virus infecting its host cells. The binding behaviors of honokiol and its analogue $6 \mathrm{p}$ with both SARS-CoV-2 spike RBD and human ACE2 protein were thus explored by a BLI binding assay. As illustrated in Figure 2 and Table 2, SARS-CoV-2 spike RBD binds to human ACE2 with an equilibrium dissociation constant $\left(\mathrm{K}_{\mathrm{D}}\right)$ value of $11.82 \mathrm{nM}$. Compound $6 \mathrm{p}$ binds to ACE2 protein with $\mathrm{K}_{\mathrm{D}}$ value of $6.87 \mu \mathrm{M}$, while it doesn't show interaction with spike RBD even in the tested concentration up to $100 \mu \mathrm{M}$. Compound 6a had a $\mathrm{K}_{\mathrm{D}}$ value of $8.41 \mu \mathrm{M}$ with ACE2 protein. Moreover, the binding ability of both $\mathbf{6 p}$ and $6 \mathbf{a}$ with human ACE2 protein was higher than that of honokiol $\left(K_{\mathrm{D}}\right.$ value of $\left.16.98 \mu \mathrm{M}\right)$. The finding revealed that $\mathbf{6 p}$ and $\mathbf{6 a}$ might effectively prevent SARS-CoV-2 from binding to the host's ACE2 receptor by blocking ACE2 receptor of host cells.

A

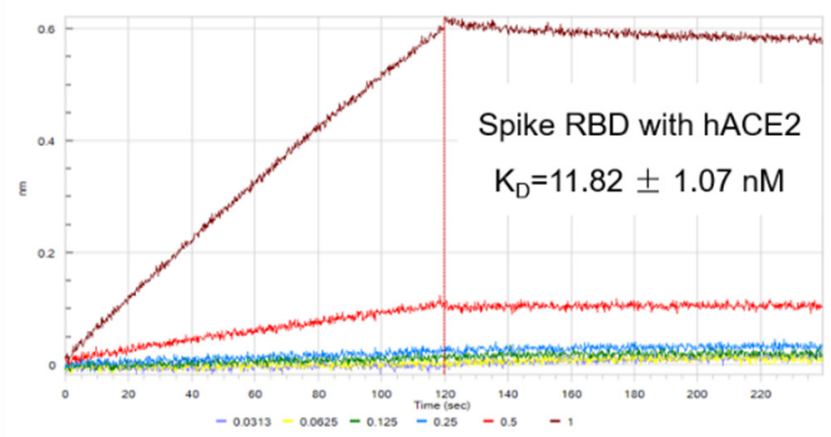

B

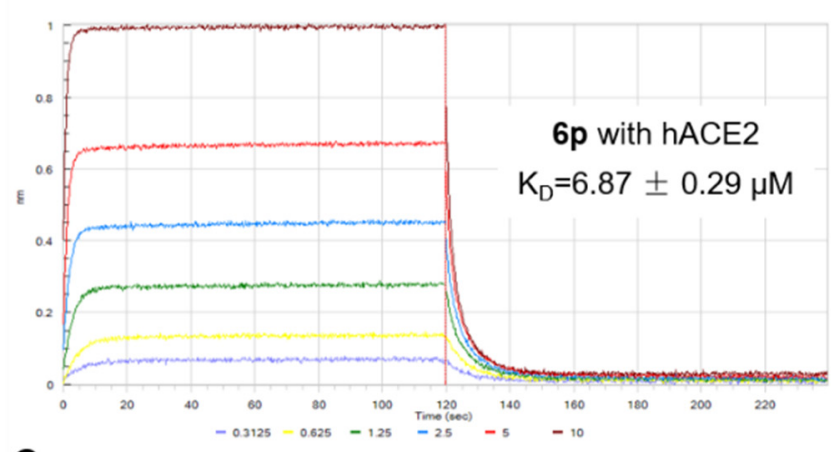

C

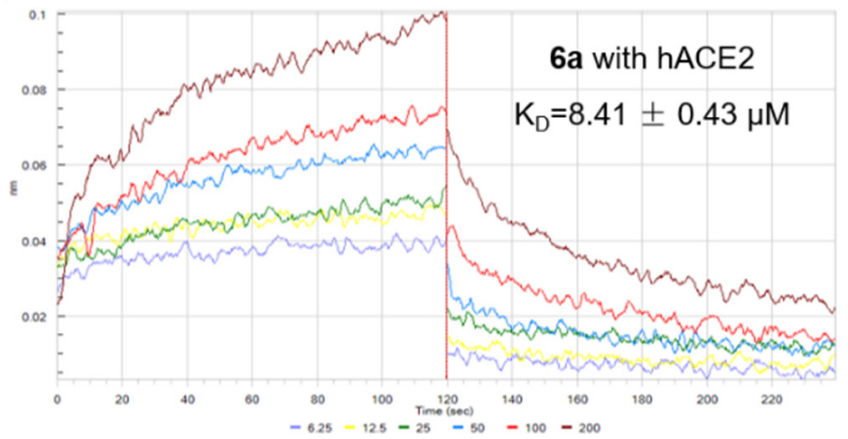

D

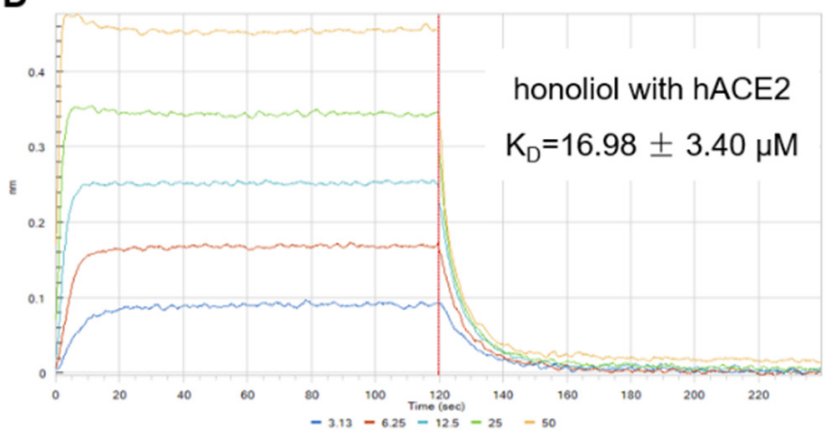

E

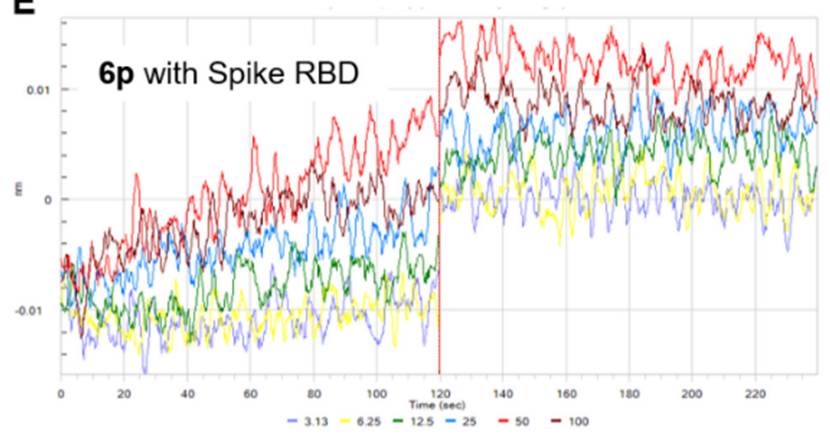

Figure 2. Binding curves of $\mathbf{6} \mathbf{p}$ and $\mathbf{6 a}$ with human ACE2 and SARS-CoV-2 spike RBD proteins. (A) The interaction of SARS-CoV-2 spike RBD $(0.03125,0.0625,0.125,0.25,0.5$ and $1 \mathrm{nM})$ with human ACE2 protein. (B) Compound 6p (0.3125, $0.625,1.25,2.5,5$ and $10 \mu \mathrm{M})$ binding to human ACE2 protein. (C) Compound $6 \mathbf{a}(6.25,12.5,25,50,100$ and $200 \mu \mathrm{M})$ binding to human ACE2 protein. (D) Honokiol $(3.125,6.25,12.5,25$ and $50 \mu \mathrm{M})$ binding to human ACE2 protein. (E) The interaction of $6 \mathbf{p}(3.125,6.25,12.5,25,50$ and $100 \mu \mathrm{M})$ with spike RBD protein. 
Table 2. Equilibrium dissociation constant $\left(K_{\mathrm{D}}\right)$ values of $\mathbf{6 a}, \mathbf{6} \mathbf{p}$, and honokiol with human ACE2 protein by BLI binding assay and their binding energy by a molecular docking study.

\begin{tabular}{ccc}
\hline Compounds & $\mathbf{K}_{\mathbf{D}}$ Values $(\boldsymbol{\mu M})$ & Binding Energy $(\mathbf{k c a l} / \mathbf{m o l})$ \\
\hline SARS-CoV-2 spike RBD & $0.01182 \pm 0.00107$ & - \\
$\mathbf{6 a}$ & $8.41 \pm 0.43$ & -59.849 \\
$\mathbf{6} \mathbf{p}$ & $6.87 \pm 0.29$ & -65.339 \\
honokiol & $16.98 \pm 3.40$ & -31.963 \\
\hline
\end{tabular}

\subsubsection{Molecular Modeling Study}

CDOCKER is an approach for producing high-precision molecular docking results under the CHARMm force field [26]. Therefore, CDOCKER of Discovery Studio software was carried out to predict the binding of $6 \mathbf{p}, 6 \mathbf{a}$ and honokiol with human ACE2 receptor (Figure 3). The data in Figure 3A showed that $\mathbf{6} \mathbf{p}$ interacts with ACE2 protein via Tyr510 and Arg514 which were the same binding sites as that of a reported ACE2 inhibitor [27]. Moreover, $\mathbf{6} \mathbf{p}$ also formed other interactions with human ACE2 protein including hydrogen bond with Asn394 and Glu398 (Figure 3A,B). A more negative binding energy indicated a more stable interaction between the compound and the protein. As reflected from the calculated binding energy of $\mathbf{6 p}(-65.339 \mathrm{kcal} / \mathrm{mol}), \mathbf{6 a}(-59.849 \mathrm{kcal} / \mathrm{mol})$ and honokiol $(-31.963 \mathrm{kcal} / \mathrm{mol})$, the binding ability of $\mathbf{6} \mathbf{p}$ and $\mathbf{6 a}$ with ACE2 is much stronger than that of honokiol (Table 2). Taken together, these data suggested that introduction of 3-((5phenyl-1,3,4-oxadiazol-2-yl)methyl)oxazol-2(3H)-ones in honokiol's molecule enhanced binding interaction of $\mathbf{6} \mathbf{p}$ and $\mathbf{6} \mathbf{a}$ with human ACE2 receptor.

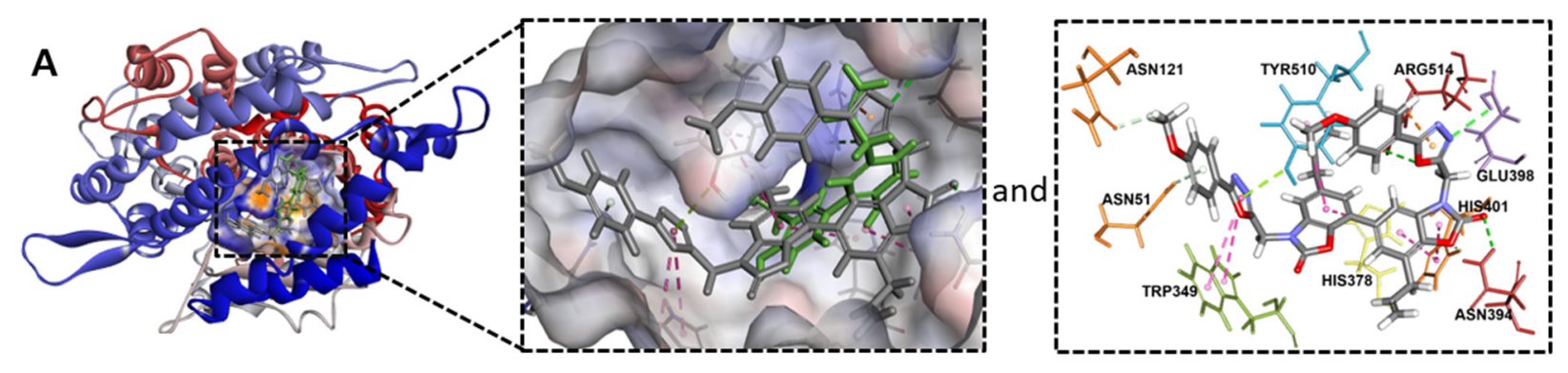

B

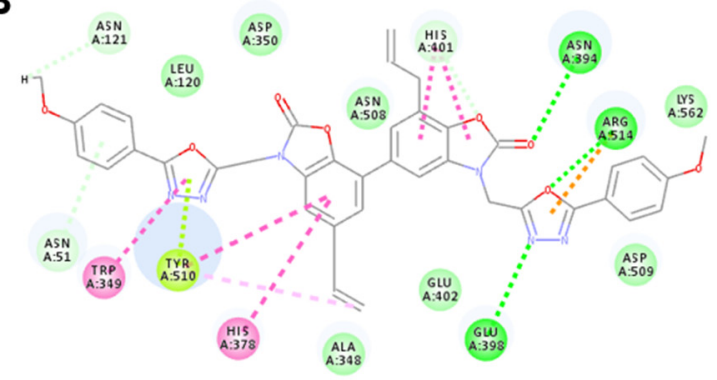

C

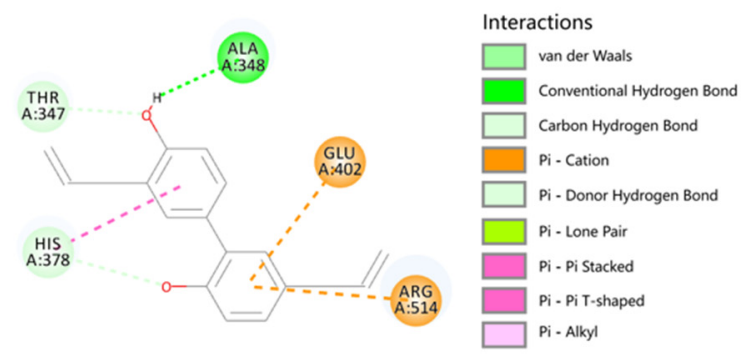

Figure 3. Docking simulation of $\mathbf{6 p}$ and honokiol in the active sites of human ACE2 receptor (PDB code: 1R4L). (A) 3D binding models of $\mathbf{6 p}$ (gray) and honokiol (green) with human ACE2. (B) 2D binding model of $\mathbf{6 p}$ with human ACE2. (C) 2D binding model of honokiol with human ACE2.

\subsubsection{Inhibitory Effect of $\mathbf{6} p$ on Binding of SARS-CoV-2 Spike RBD with ACE2 Protein}

A competitive ELISA assay was conducted to further investigate the interventive effect of compound $6 \mathrm{p}$ on the binding of SARS-CoV-2 spike RBD with ACE2 protein. A SARS-CoV-2 antibody inhibitor ( $\mathrm{IC}_{50}$ value of $2.59 \mathrm{nM}$ ) was employed as a positive control in this assay. As a result (Figure 4 ), $\mathbf{6} \mathbf{p}$ can suppress the binding of spike RBD and ACE2 with inhibitory rate of $26.08 \%, 37.16 \%$, and $50.41 \%$ under tested concentration of $12.5,25$, and $50 \mu \mathrm{M}$, respectively. Honokiol also showed a relatively weak inhibitory rate of $13.81 \%$ 
and $20.94 \%$ under 25 and $50 \mu \mathrm{M}$, respectively. In conjunction with the BLI and molecular simulation results, the dose-dependent inhibitory effect of $6 \mathbf{p}$ on spike RBD's binding with ACE2 provided supporting evidence that $6 \mathbf{p}$ occupied the active sites of ACE2 to prevent the attachment of spike RBD.

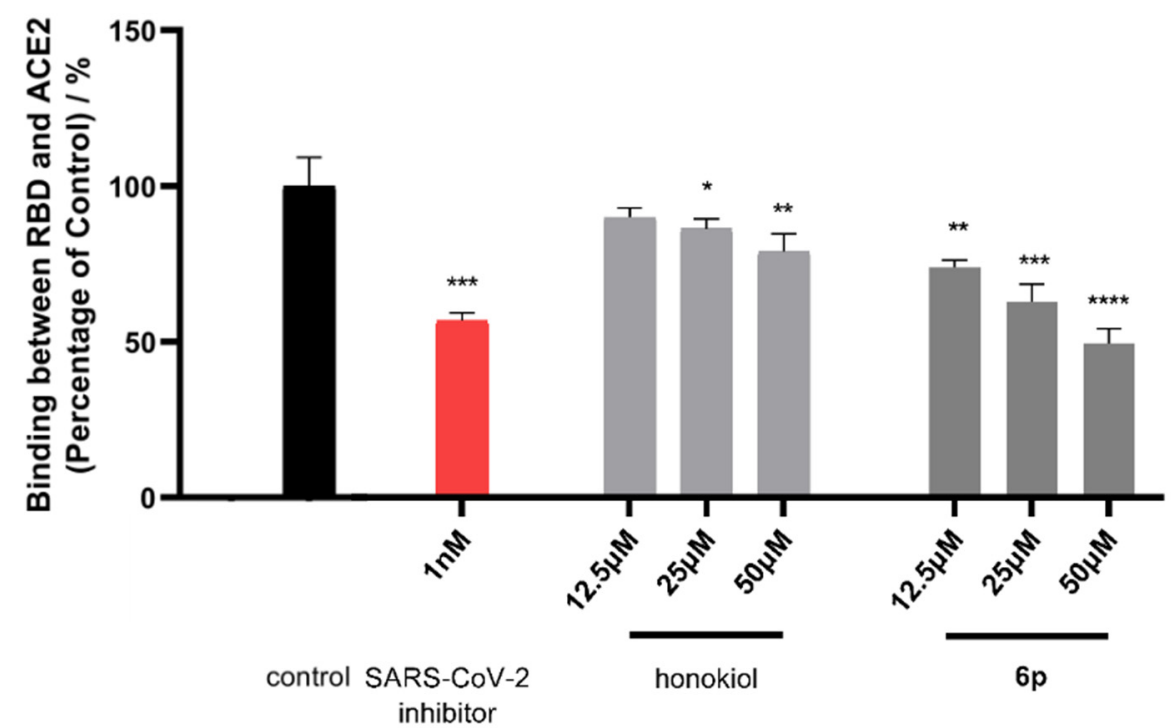

Figure 4. Binding activity of SARS-CoV-2 spike RBD with ACE2 protein in the absence (control) and presence of honokiol and $6 \mathbf{p}(12.5,25$ and $50 \mu \mathrm{M})$ by a competitive ELISA assay. A SARS-CoV-2 antibody inhibitor ( $1 \mathrm{nM})$ was utilized as a positive control. The OD value of the control group was defined as $100 \%$. The OD values of either antibody inhibitor-treated or compound-treated groups were normalized accordingly. Results were expressed as mean \pm standard error $(\mathrm{n}=3) .{ }^{*} p<0.05$, ${ }^{* *} p<0.01,{ }^{* * *} p<0.001,{ }^{* * *} p<0.0001$ compared with the control group. The experiments were repeated three times.

\subsubsection{Structure-Activity Relationship Analysis}

Based on the above findings, an analysis of structure-activity relationship (SAR) was concluded as follows. Firstly, 3-((5-phenyl-1,3,4-oxadiazol-2-yl)methyl)oxazol-2(3H)-one was an indispensable functional group for the antiviral entry activity of $\mathbf{6 a}$. The introduction of this functional group to honokiol resulted in an $\mathrm{IC}_{50}$ value of $29.23 \mu \mathrm{M}$ against entry of SARS-CoV-2 spike pseudotyped virus into host cells, a potent binding affinity $\left(\mathrm{K}_{\mathrm{D}}\right.$ value of $8.41 \mu \mathrm{M})$ with ACE2 protein, and a low binding energy $(-59.849 \mathrm{kcal} / \mathrm{mol})$ with ACE2 protein when compared with that of the parental honokiol. Moreover, the cytotoxicity of $\mathbf{6 a}$ $\left(\mathrm{TC}_{50}>100 \mu \mathrm{M}\right)$ was also much lower than that $\left(\mathrm{TC}_{50}\right.$ of $\left.48.23 \mu \mathrm{M}\right)$ of the parental honokiol against HEK-293T-ACE2 ${ }^{\mathrm{h}}$ cells. Secondly, an electron-donating methoxyl substituent at the para-position of $\mathbf{6 a}$ was more beneficial to enhance the antiviral entry activity of $\mathbf{6} \mathbf{p}$ due to the fact that $\mathbf{6 p}\left(\mathrm{IC}_{50}\right.$ of $\left.9.82 \mu \mathrm{M}\right)$ exhibited 2.97 times greater inhibitory activity against pseudovirus entry and a more potent binding affinity (KD value of $6.87 \mu \mathrm{M}$ ) with ACE2 protein than $\mathbf{6 a}$. The importance of methoxyl at the para-position of $\mathbf{6 a}$ was also supported by the evidence that $6 \mathbf{p}$ had a more stable interaction (binding energy $-65.339 \mathrm{kcal} / \mathrm{mol}$ ) with ACE2 protein than 6 a probably due to the additional carbon hydrogen bonding interaction of one methoxyl with the Asn121 site in ACE2 (Figure 3A,B). Thirdly, the electron-withdrawing -F group at ortho-position of 6a led to a 2.10-fold loss in antiviral entry activity of $6 \mathbf{h}\left(\mathrm{IC}_{50}\right.$ of $\left.61.58 \mu \mathrm{M}\right)$, while the presence of $-\mathrm{F}$ at meta- and para-positions of $6 \mathbf{a}$ resulted in complete loss of antiviral activities of both $\mathbf{6 i}$ and $\mathbf{6 j}$. It was postulated that the presence of $-\mathrm{F}$ group may reduce the binding stability of 6a with ACE2. Finally, other electron-withdrawing $-\mathrm{Cl},-\mathrm{Br}$, and electron-donating methyl substituents at any position of $\mathbf{6 a}$ also led to complete loss of antiviral entry activities. 


\section{Materials and Methods}

3.1. Reagents and Apparatus

Honokiol was obtained from Xianding Biological Technology Co., Ltd. (Shanghai, China). Various substituted benzoic acids, chloroacetyl chloride, stannous chloride, and phosphorus oxychloride were purchased from J \& K Scientific Ltd. and used without further purification. Melting points (m.p.) of all honokiol derivatives were measured by a digital melting-point apparatus (XT-4, Beijing, China) that was not corrected. Infrared spectra (IR) were determined by a FT-IR spectrometer (PE-1710, Waltham, MA, USA). A Bruker 400/100 MHz NMR spectrometer (Avance, Bremerhaven, Germany) was used to measure ${ }^{1} \mathrm{H}$ and ${ }^{13} \mathrm{C}$ NMR spectra of honokiol derivatives 6a-p. High resolution mass spectra (HRMS) were measured on an Agilent 6545 ESI-QTOF-MS instrument (Agilent Technologies, Santa Clara, CA, USA). The purities of all synthetic derivatives were determined on an Agilent 1200 HPLC-DAD apparatus.

\subsection{Synthesis of 2-chloromethyl-5-substituted phenyl-1,3,4-oxadiazoles 5a-p, and Compounds 2-4}

To a solution of substituted benzoic acids a-p $(10 \mathrm{mmol})$ in $\mathrm{EtOH}(15 \mathrm{~mL})$, concentrated sulfuric acid $(0.1 \mathrm{~mL})$ was added, and the reaction solution was refluxed for $24 \mathrm{~h}$. Then the solution was evaporated under reduced pressure, and the mixture was purified by silica gel column chromatography (CC) to afford compounds 2a-p. Subsequently, compounds 2a-p were reacted with hydrazine hydrate $(15 \mathrm{mmol})$ in $\mathrm{EtOH}$ under reflux to obtain various substituted benzoyl hydrazines 3a-p. Chloroacetylation of 3a-p was performed with chloroacetyl chloride $(10 \mathrm{mmol})$ in EtOAc under reflux condition to afford compounds 4a-p. Finally, compounds 4a-p were treated with $\mathrm{POCl}_{3}$ at $90-100{ }^{\circ} \mathrm{C}$ to successfully obtain the key intermediates of 2-chloromethyl-5-substituted phenyl-1,3,4-oxadiazoles 5a-p.

To a solution of honokiol $(37.5 \mathrm{mmol})$ in acetic acid $(10 \mathrm{~mL})$, concentrated nitric acid (112.7 $\mathrm{mmol}$ ) was slowly added. When the reaction was completed, the mixture was poured into ice water and adjusted to $\mathrm{pH}=7$ with $5 \%$ sodium bicarbonate solution, then extracted with dichloromethane $(20 \mathrm{~mL} \times 3)$. The organic layer was dried with anhydrous sodium sulfate, concentrated under reduced pressure, and purified by silica gel CC to obtain 3,5'-dinitrohonokiol (2). A mixture of compound $2(30 \mathrm{mmol})$ and $\mathrm{SnCl}_{2}(90 \mathrm{mmol})$ was dissolved in $\mathrm{EtOH}$, and stirred at $25^{\circ} \mathrm{C}$. After the reaction was completed, the reaction solution was concentrated in vacuo, then the residue was diluted by EtOAc and adjusted to $\mathrm{pH}=7$ with $5 \%$ sodium bicarbonate solution. Finally, the EtOAc solution was dried over anhydrous $\mathrm{Na}_{2} \mathrm{SO}_{4}$, concentrated by a rotary evaporator, and purified by silica gel CC to give the product of $3,5^{\prime}$-diaminohonokiol (3). A mixture of compound $3(20 \mathrm{mmol})$ and urea $\left(80 \mathrm{mmol}\right.$ ) was stirred at $140^{\circ} \mathrm{C}$ for about $12 \mathrm{~h}$. When the reaction was completed according to the TLC analysis, $10 \%$ hydrochloric acid solution was added to the reaction mixture, and then the mixture was extracted with ethyl acetate $(20 \mathrm{~mL} \times 3)$. Subsequently, the organic layer was dried over $\mathrm{Na}_{2} \mathrm{SO}_{4}$, concentrated under reduced pressure, and purified by silica gel CC to obtain cyclized product 4 .

\subsection{Synthesis of Compounds $\mathbf{6 a - p}$}

To a solution of compound $4(0.5 \mathrm{mmol})$ in acetone $(5 \mathrm{~mL}), \mathrm{K}_{2} \mathrm{CO}_{3}(1.5 \mathrm{mmol}), \mathrm{KI}(0.1$ $\mathrm{mmol}$ ), and the corresponding 2-chloromethyl-5-substituted phenyl-1,3,4-oxadiazoles 5a-p $(0.6 \mathrm{mmol})$ were added, and then the reaction mixture was stirred at room temperature. When the reaction was completed, the mixture was filtered, concentrated under reduced pressure, and finally purified by PTLC to obtain the target compounds 6a-p. The structural identification data of compound 6a-p (Figures S1-S47) were illustrated as follows.

Data for 6a: White solid, yield: $85 \%$, m.p. $202-205^{\circ} \mathrm{C}$; IR cm ${ }^{-1}(\mathrm{KBr}): 1776,1446,1342$, 1067, 707, 690; ${ }^{1} \mathrm{H}$ NMR $\left(400 \mathrm{MHz} \mathrm{CDCl}_{3}\right) \delta: 7.99-8.03(\mathrm{~m}, 4 \mathrm{H},-\mathrm{Ph}), 7.47-7.54(\mathrm{~m}, 6 \mathrm{H},-\mathrm{Ph})$, $7.31(\mathrm{~s}, 2 \mathrm{H},-\mathrm{Ph}), 7.04(\mathrm{~s}, 1 \mathrm{H},-\mathrm{Ph}), 6.97(\mathrm{~d}, J=1.2 \mathrm{~Hz}, 1 \mathrm{H},-\mathrm{Ph}), 5.90-6.00\left(\mathrm{~m}, 2 \mathrm{H},-\mathrm{CH}=\mathrm{CH}_{2}\right)$, $5.38\left(\mathrm{~s}, 2 \mathrm{H},-\mathrm{C}_{2}-\mathrm{N}\right), 5.34\left(\mathrm{~s}, 2 \mathrm{H},-\underline{\mathrm{C}}_{2}-\mathrm{N}\right), 5.09-5.20\left(\mathrm{~m}, 4 \mathrm{H},-\mathrm{CH}=\mathrm{CH}_{2}\right), 3.56(\mathrm{~d}, J=6.8 \mathrm{~Hz}$, $\left.2 \mathrm{H},-\mathrm{CH}_{2}-\mathrm{CH}=\mathrm{CH}_{2}\right), 3.43\left(\mathrm{~d}, J=6.4 \mathrm{~Hz}, 2 \mathrm{H},-\mathrm{CH}_{2}-\mathrm{CH}=\mathrm{CH}_{2}\right) ;{ }^{13} \mathrm{C} \mathrm{NMR}\left(100 \mathrm{MHz} \mathrm{CDCl}_{3}\right)$ $\delta: 166.13,160.23,153.97,140.80,138.03,137.39,136.56,134.39,132.29,132.24,131.22,130.53$, 
$130.14,129.14,129.11,127.18,124.61,123.62,123.39,123.11,117.36,116.82,108.23,106.89$, 40.07, 36.88, 33.33; HRMS: calcd for $\mathrm{C}_{38} \mathrm{H}_{29} \mathrm{~N}_{6} \mathrm{O}_{6}\left([\mathrm{M}+\mathrm{H}]^{+}\right)$665.2070, found 665.2145.

Data for 6b: White solid, yield: $70 \%$, m.p. $167-170{ }^{\circ} \mathrm{C}$; IR $\mathrm{cm}^{-1}(\mathrm{KBr}): 2923,1776$, 1581, 1442, 1342, 731; ${ }^{1} \mathrm{H}$ NMR (400 $\left.\mathrm{MHz} \mathrm{CDCl}_{3}\right) \delta: 7.93-7.97$ (m, 2H, -Ph), 7.31-7.52 (m, $8 \mathrm{H},-\mathrm{Ph}), 7.05(\mathrm{~d}, J=1.2 \mathrm{~Hz}, 1 \mathrm{H},-\mathrm{Ph}), 6.97(\mathrm{~d}, J=1.2 \mathrm{~Hz}, 1 \mathrm{H},-\mathrm{Ph}), 5.90-6.00(\mathrm{~m}, 2 \mathrm{H}$, $\left.-\mathrm{CH}=\mathrm{CH}_{2}\right), 5.41\left(\mathrm{~s}, 2 \mathrm{H},-\mathrm{CH}_{2}-\mathrm{N}\right), 5.37\left(\mathrm{~s}, 2 \mathrm{H},-\mathrm{CH}_{2}-\mathrm{N}\right), 5.09-5.20\left(\mathrm{~m}, 4 \mathrm{H},-\mathrm{CH}=\mathrm{CH}_{2}\right), 3.56$ $\left(\mathrm{d}, \mathrm{J}=6.8 \mathrm{~Hz}, 2 \mathrm{H},-\mathrm{CH}_{2}-\mathrm{CH}=\mathrm{CH}_{2}\right), 3.44\left(\mathrm{~d}, \mathrm{~J}=6.8 \mathrm{~Hz}, 2 \mathrm{H},-\mathrm{CH}_{2}-\mathrm{CH}=\mathrm{CH}_{2}\right) ;{ }^{13} \mathrm{C} \mathrm{NMR}(100$ $\mathrm{MHz} \mathrm{CDCl}_{3}$ ) $\delta: 164.42,164.38,160.66,160.65,153.91,140.81,138.03,137.35,136.55,134.38$, $133.35,133.32,132.88,132.81,131.34,131.29,131.17,130.50,130.12,127.16,127.14,124.61$, 123.60, 123.40, 122.40, 117.35, 116.84, 108.24, 106.89, 40.08, 36.93, 36.88, 33.33; HRMS: calcd for $\mathrm{C}_{38} \mathrm{H}_{27}{ }^{35} \mathrm{Cl}_{2} \mathrm{~N}_{6} \mathrm{O}_{6}\left([\mathrm{M}+\mathrm{H}]^{+}\right)$733.1291, found 733.1363; calcd for $\mathrm{C}_{38} \mathrm{H}_{27}{ }^{35} \mathrm{Cl}^{37} \mathrm{ClN}_{6} \mathrm{O}_{6}$ $\left([\mathrm{M}+\mathrm{H}]^{+}\right)$735.1291, found 735.1346.

Data for 6c: White solid, yield: $93 \%$, m.p. $155-158^{\circ} \mathrm{C}$; IR cm ${ }^{-1}(\mathrm{KBr}): 2972,1784,1770$, 1438, 1343, 1042; ${ }^{1} \mathrm{H}$ NMR (400 $\left.\mathrm{MHz} \mathrm{CDCl}_{3}\right) \delta: 7.90-8.01$ (m, 4H, -Ph), 7.42-7.51 (m, 4H, -Ph), 7.31 (s, 2H, $-\mathrm{Ph}), 7.05(\mathrm{~d}, J=1.2 \mathrm{~Hz}, 1 \mathrm{H},-\mathrm{Ph}), 6.97(\mathrm{~d}, J=1.2 \mathrm{~Hz}, 1 \mathrm{H},-\mathrm{Ph}), 5.90-6.00$ (m, $\left.2 \mathrm{H},-\mathrm{C} \underline{H}=\mathrm{CH}_{2}\right), 5.39\left(\mathrm{~s}, 2 \mathrm{H},-\mathrm{C}_{2}-\mathrm{N}\right), 5.34\left(\mathrm{~s}, 2 \mathrm{H},-\mathrm{CH}_{2}-\mathrm{N}\right), 5.10-5.20\left(\mathrm{~m}, 4 \mathrm{H},-\mathrm{CH}=\mathrm{CH}_{2}\right)$, $3.56\left(\mathrm{~d}, J=6.4 \mathrm{~Hz}, 2 \mathrm{H},-\underline{\mathrm{CH}}_{2}-\mathrm{CH}=\mathrm{CH}_{2}\right), 3.44\left(\mathrm{~d}, \mathrm{~J}=6.8 \mathrm{~Hz}, 2 \mathrm{H},-\underline{\mathrm{CH}}_{2}-\mathrm{CH}=\mathrm{CH}_{2}\right) ;{ }^{13} \mathrm{C}$ NMR $\left(100 \mathrm{MHz} \mathrm{CDCl}_{3}\right) \delta: 165.03,164.99,160.55,160.52,153.91,153.87,140.80,138.00,137.43$, 136.52, 135.34, 135.28, 134.34, 132.37, 132.31, 131.18, 130.50, 130.45, 130.05, 124.68, 124.62, $123.69,123.61,123.42,117.40,116.89,108.16,106.85,40.07,36.87,36.81,33.34$; HRMS: calcd for $\mathrm{C}_{38} \mathrm{H}_{27}{ }^{35} \mathrm{Cl}_{2} \mathrm{~N}_{6} \mathrm{O}_{6}\left([\mathrm{M}+\mathrm{H}]^{+}\right)$733.1291, found 733.1371; calcd for $\mathrm{C}_{38} \mathrm{H}_{27}{ }^{35} \mathrm{Cl}^{37} \mathrm{ClN}_{6} \mathrm{O}_{6}$ $\left([\mathrm{M}+\mathrm{H}]^{+}\right)$735.1291, found 735.1354.

Data for 6d: White solid, yield: 66\%, m.p. $190-193{ }^{\circ} \mathrm{C}$; IR $\mathrm{cm}^{-1}(\mathrm{KBr}): 2972,1776$, 1609, 1483, 1442, 1095; ${ }^{1} \mathrm{H}$ NMR (400 $\left.\mathrm{MHz} \mathrm{CDCl}_{3}\right) \delta: 7.94-7.98$ (m, 4H, -Ph), 7.45-7.48 (m, $4 \mathrm{H},-\mathrm{Ph}), 7.30-7.32(\mathrm{~m}, 2 \mathrm{H},-\mathrm{Ph}), 7.04(\mathrm{~d}, J=1.2 \mathrm{~Hz}, 1 \mathrm{H},-\mathrm{Ph}), 6.97$ (d, J = 1.2 Hz, 1H, -Ph), 5.90-6.02 (m, 2H, $\left.-\mathrm{CH}=\mathrm{CH}_{2}\right), 5.38\left(\mathrm{~s}, 2 \mathrm{H},-\mathrm{CH}_{2}-\mathrm{N}\right), 5.33\left(\mathrm{~s}, 2 \mathrm{H},-\mathrm{CH}_{2}-\mathrm{N}\right), 5.10-5.20(\mathrm{~m}, 4 \mathrm{H}$, $\left.-\mathrm{CH}=\mathrm{CH}_{2}\right), 3.56\left(\mathrm{~d}, J=6.8 \mathrm{~Hz}, 2 \mathrm{H},-\underline{\mathrm{C}}_{2}-\mathrm{CH}=\mathrm{CH}_{2}\right), 3.43\left(\mathrm{~d}, J=6.8 \mathrm{~Hz}, 2 \mathrm{H},-\underline{\mathrm{C}}_{2}-\mathrm{CH}=\mathrm{CH}_{2}\right)$; ${ }^{13} \mathrm{C} \mathrm{NMR}\left(100 \mathrm{MHz} \mathrm{CDCl}_{3}\right) \delta: 165.36,160.37,153.91,140.80,138.71,138.65,137.43,136.54$, $134.35,131.18,130.48,130.08,129.57,129.55,128.47,128.45,124.58,123.69,123.62,123.41$, $121.55,117.40,116.85,108.20,106.88,40.06,36.83,33.33$; HRMS: calcd for $\mathrm{C}_{38} \mathrm{H}_{27}{ }^{35} \mathrm{Cl}_{2} \mathrm{~N}_{6} \mathrm{O}_{6}$ $\left([\mathrm{M}+\mathrm{H}]^{+}\right)$733.1291, found 733.1364; calcd for $\mathrm{C}_{38} \mathrm{H}_{27}{ }^{35} \mathrm{Cl}^{37} \mathrm{ClN}_{6} \mathrm{O}_{6}\left([\mathrm{M}+\mathrm{H}]^{+}\right) 735.1291$, found 735.1344 .

Data for 6e: White solid, yield: 57\%, m.p. $147-150{ }^{\circ} \mathrm{C}$; IR cm ${ }^{-1}(\mathrm{KBr}): 2979,1778$, 1442, 1343, 757, 727; ${ }^{1} \mathrm{H}$ NMR (400 $\left.\mathrm{MHz} \mathrm{CDCl}_{3}\right) \delta: 7.88-7.90$ (m, 2H, -Ph), 7.67-7.73 (m, 2H, -Ph), 7.31-7.44 (m, 6H, -Ph), 7.05 (d, J = 1.2 Hz, 1H, -Ph), 6.96 (d, J = 1.2 Hz, 1H, -Ph), 5.93-6.00 (m, 2H, $\left.-\mathrm{C} \underline{H}=\mathrm{CH}_{2}\right), 5.41\left(\mathrm{~s}, 2 \mathrm{H},-\mathrm{CH}_{2}-\mathrm{N}\right), 5.37\left(\mathrm{~s}, 2 \mathrm{H},-\mathrm{C}_{2}-\mathrm{N}\right), 5.09-5.20(\mathrm{~m}, 4 \mathrm{H}$, $\left.-\mathrm{CH}=\mathrm{CH}_{2}\right), 3.56\left(\mathrm{~d}, \mathrm{~J}=6.4 \mathrm{~Hz}, 2 \mathrm{H},-\mathrm{C}_{2}-\mathrm{CH}=\overline{\mathrm{CH}}_{2}\right), 3.44\left(\mathrm{~d}, \mathrm{~J}=6.8 \mathrm{~Hz}, 2 \mathrm{H},-\mathrm{C}_{2}-\mathrm{CH}=\mathrm{CH}_{2}\right)$; ${ }^{13} \mathrm{C} \mathrm{NMR}\left(100 \mathrm{MHz} \mathrm{CDCl}_{3}\right) \delta: 164.95,164.90,160.71,153.94,140.83,138.04,137.35,136.55$, $134.65,134.59,134.38,132.95,132.88,131.80,131.76,131.16,130.50,130.11,127.67,127.65$, $124.61,124.50,123.61,123.39,121.77,121.73,117.36,116.86,108.25,106.91,40.08,36.91$, 33.33; HRMS: calcd for $\mathrm{C}_{38} \mathrm{H}_{27}{ }^{79} \mathrm{Br}_{2} \mathrm{~N}_{6} \mathrm{O}_{6}\left([\mathrm{M}+\mathrm{H}]^{+}\right)$821.0281, found 821.0354; calcd for $\mathrm{C}_{38} \mathrm{H}_{27}{ }^{79} \mathrm{Br}^{81} \mathrm{BrN}_{6} \mathrm{O}_{6}\left([\mathrm{M}+\mathrm{H}]^{+}\right)$823.0281, found 823.0343; calcd for $\mathrm{C}_{38} \mathrm{H}_{27}{ }^{81} \mathrm{Br}^{81} \mathrm{BrN}_{6} \mathrm{O}_{6}$ $\left([\mathrm{M}+\mathrm{H}]^{+}\right)$825.0281, found 825.0330.

Data for 6f: White solid, yield: 79\%, m.p. 127-130 ${ }^{\circ} \mathrm{C}$; IR cm ${ }^{-1}(\mathrm{KBr}): 3066,2965,1772$, 1444, 1342, 722; ${ }^{1} \mathrm{H}$ NMR (400 $\left.\mathrm{MHz} \mathrm{CDCl}_{3}\right) \delta$ : 8.15-8.17 (m, 2H, -Ph), 7.95-7.98 (m, 2H, -Ph), 7.64-7.66 (m, 2H, -Ph), 7.31-7.39 (m, 4H, -Ph), 7.05 (d, J = 0.8 Hz, 1H, -Ph), $6.97(\mathrm{~d}, J=$ $1.2 \mathrm{~Hz}, 1 \mathrm{H},-\mathrm{Ph}), 5.91-6.03\left(\mathrm{~m}, 2 \mathrm{H},-\mathrm{C} \underline{H}=\mathrm{CH}_{2}\right), 5.39\left(\mathrm{~s}, 2 \mathrm{H},-\underline{\mathrm{H}}_{2}-\mathrm{N}\right), 5.34\left(\mathrm{~s}, 2 \mathrm{H},-\underline{\mathrm{H}}_{2}-\mathrm{N}\right)$, $5.10-5.21\left(\mathrm{~m}, 4 \mathrm{H},-\mathrm{CH}=\mathrm{CH}_{2}\right), 3.56\left(\mathrm{~d}, \mathrm{~J}=6.8 \mathrm{~Hz}, 2 \mathrm{H},-\mathrm{CH}_{2}-\mathrm{CH}=\mathrm{CH}_{2}\right), 3.44(\mathrm{~d}, J=6.8 \mathrm{~Hz}$, $\left.2 \mathrm{H},-\mathrm{CH}_{2}-\mathrm{CH}=\mathrm{CH}_{2}\right) ;{ }^{13} \mathrm{C} \mathrm{NMR}\left(100 \mathrm{MHz} \mathrm{CDCl}_{3}\right) \delta: 164.89,164.84,160.56,160.53,153.91$, $153.88,140.80,138.01,137.44,136.52,135.29,135.23,134.34,131.18,130.71,130.45,130.05$, $129.98,125.71,124.89,124.62,123.70,123.61,123.42,123.18,123.13,117.40,116.90,108.16$, 106.86, 40.07, 36.87, 36.81, 33.34; HRMS: calcd for $\mathrm{C}_{38} \mathrm{H}_{27}{ }^{79} \mathrm{Br}_{2} \mathrm{~N}_{6} \mathrm{O}_{6}\left([\mathrm{M}+\mathrm{H}]^{+}\right)$821.0281, found 821.0349; calcd for $\mathrm{C}_{38} \mathrm{H}_{27}{ }^{79} \mathrm{Br}^{81} \mathrm{BrN}_{6} \mathrm{O}_{6}\left([\mathrm{M}+\mathrm{H}]^{+}\right)$823.0281, found 823.0330; calcd for $\mathrm{C}_{38} \mathrm{H}_{27}{ }^{81} \mathrm{Br}^{81} \mathrm{BrN}_{6} \mathrm{O}_{6}\left([\mathrm{M}+\mathrm{H}]^{+}\right)$825.0281, found 825.0319. 
Data for 6g: White solid, yield: $87 \%$, m.p. $232-235^{\circ} \mathrm{C}$; IR cm ${ }^{-1}(\mathrm{KBr}): 2923,1776$, 1603, 1480, 1441, 1009; ${ }^{1} \mathrm{H}$ NMR (400 MHz $\left.\mathrm{CDCl}_{3}\right)$ 8: 7.87-7.90 (m, 4H, -Ph), 7.62-7.65 (m, $4 \mathrm{H},-\mathrm{Ph}), 7.30-7.32(\mathrm{~m}, 2 \mathrm{H},-\mathrm{Ph}), 7.04(\mathrm{~d}, J=1.6 \mathrm{~Hz}, 1 \mathrm{H},-\mathrm{Ph}), 6.97(\mathrm{~d}, J=1.2 \mathrm{~Hz}, 1 \mathrm{H},-\mathrm{Ph})$, 5.90-6.02 (m, 2H, $\left.-\mathrm{C} \underline{H}=\mathrm{CH}_{2}\right), 5.38\left(\mathrm{~s}, 2 \mathrm{H},-\underline{\mathrm{H}}_{2}-\mathrm{N}\right), 5.33\left(\mathrm{~s}, 2 \mathrm{H},-\mathrm{C}_{2}-\mathrm{N}\right), 5.09-5.20(\mathrm{~m}, 4 \mathrm{H}$, $\left.-\mathrm{CH}=\mathrm{CH}_{2}\right), 3.56\left(\mathrm{~d}, J=6.8 \mathrm{~Hz}, 2 \mathrm{H},-\mathrm{CH}_{2}-\mathrm{CH}=\mathrm{CH}_{2}\right), 3.43\left(\mathrm{~d}, J=6.4 \mathrm{~Hz}, 2 \mathrm{H},-\mathrm{CH}_{2}-\mathrm{CH}=\mathrm{CH}_{2}\right)$; ${ }^{13} \mathrm{C} \mathrm{NMR}\left(100 \mathrm{MHz} \mathrm{CDCl}_{3}\right) \delta: 165.46,160.45,153.93,140.77,140.30,138.07,137.49,136.60$, $134.43,132.57,132.53,131.22,130.63,130.17,128.58,127.19,124.60,123.73,123.63,123.45$, 122.00, 117.42, 116.88, 108.22, 106.89, 40.07, 36.87, 33.37; HRMS: calcd for $\mathrm{C}_{38} \mathrm{H}_{27}{ }^{79} \mathrm{Br}_{2} \mathrm{~N}_{6} \mathrm{O}_{6}$ $\left([\mathrm{M}+\mathrm{H}]^{+}\right)$821.0281, found 821.0351; calcd for $\mathrm{C}_{38} \mathrm{H}_{27}{ }^{79} \mathrm{Br}^{81} \mathrm{BrN}_{6} \mathrm{O}_{6}\left([\mathrm{M}+\mathrm{H}]^{+}\right)$823.0281, found 823.0339; calcd for $\mathrm{C}_{38} \mathrm{H}_{27}{ }^{81} \mathrm{Br}^{81} \mathrm{BrN}_{6} \mathrm{O}_{6}\left([\mathrm{M}+\mathrm{H}]^{+}\right)$825.0281, found 825.0326.

Data for 6h: White solid, yield: $49 \%$, m.p. $160-163{ }^{\circ} \mathrm{C}$; IR cm ${ }^{-1}(\mathrm{KBr}): 2967,1770,1619$, 1470, 1442, 1340; ${ }^{1} \mathrm{H}$ NMR $\left(400 \mathrm{MHz} \mathrm{CDCl}_{3}\right) \delta: 7.98-8.04(\mathrm{~m}, 2 \mathrm{H},-\mathrm{Ph}), 7.52-7.55(\mathrm{~m}, 2 \mathrm{H}$, -Ph), 7.28-7.32 (m, 4H, -Ph), 7.18-7.25 (m, 2H, -Ph), $7.05(\mathrm{~d}, J=1.2 \mathrm{~Hz}, 1 \mathrm{H},-\mathrm{Ph}), 6.98(\mathrm{~d}, J=$ $1.2 \mathrm{~Hz}, 1 \mathrm{H},-\mathrm{Ph}), 5.91-6.00\left(\mathrm{~m}, 2 \mathrm{H},-\mathrm{C} \underline{H}=\mathrm{CH}_{2}\right), 5.40\left(\mathrm{~s}, 2 \mathrm{H},-\mathrm{C}_{2}-\mathrm{N}\right), 5.36\left(\mathrm{~s}, 2 \mathrm{H},-\mathrm{C}_{2}-\mathrm{N}\right)$, $5.09-5.20\left(\mathrm{~m}, 4 \mathrm{H},-\mathrm{CH}=\mathrm{CH}_{2}\right), 3.56\left(\mathrm{~d}, J=6.8 \mathrm{~Hz}, 2 \mathrm{H},-\mathrm{CH}_{2}-\mathrm{CH}=\mathrm{CH}_{2}\right), 3.44(\mathrm{~d}, J=6 . \overline{\mathrm{Hz}}$, $\left.2 \mathrm{H},-\mathrm{CH}_{2}-\mathrm{CH}=\mathrm{CH}_{2}\right) ;{ }^{13} \mathrm{C} \overline{\mathrm{NMR}}\left(100 \mathrm{MHz} \mathrm{CDCl}_{3}\right) \delta: 162.93,162.84,160.61,160.53,160.17(\mathrm{~d}$, $\left.J_{C F}=254.0 \mathrm{~Hz}\right), 153.93,153.91,140.84,139.43,138.60,138.07,137.41,136.58,134.41,134.16$, $134.09,132.82$, 131.20, 130.53, 130.15, 129.92, 128.19, 124.74, 123.60, 123.42, 119.95, 117.34, $117.19,117.01,116.83,111.77,108.30,106.89,40.08,36.92,36.84,33.32$; HRMS: calcd for $\mathrm{C}_{38} \mathrm{H}_{27} \mathrm{~F}_{2} \mathrm{~N}_{6} \mathrm{O}_{6}\left([\mathrm{M}+\mathrm{H}]^{+}\right)$701.1882, found 701.1959.

Data for 6i: White solid, yield: $25 \%$, m.p. $166-168^{\circ} \mathrm{C}$; $\mathrm{IR} \mathrm{cm}{ }^{-1}(\mathrm{KBr}): 2922,1770,1440$, 870, 728, 681; ${ }^{1} \mathrm{H}$ NMR $\left(400 \mathrm{MHz} \mathrm{CDCl}_{3}\right) \delta: 7.80-7.83(\mathrm{~m}, 2 \mathrm{H},-\mathrm{Ph}), 7.70-7.74(\mathrm{~m}, 2 \mathrm{H},-\mathrm{Ph})$, 7.45-7.49 (m, 2H, -Ph), 7.31-7.32 (m, 2H, -Ph), 7.20-7.25 (m, 2H, -Ph), $7.05(\mathrm{~d}, J=1.6 \mathrm{~Hz}, 1 \mathrm{H}$, $-\mathrm{Ph}), 6.97(\mathrm{~d}, J=1.2 \mathrm{~Hz}, 1 \mathrm{H},-\mathrm{Ph}), 5.91-6.03\left(\mathrm{~m}, 2 \mathrm{H},-\mathrm{C} \underline{H}=\mathrm{CH}_{2}\right), 5.39\left(\mathrm{~s}, 2 \mathrm{H},-\mathrm{CH}_{2}-\mathrm{N}\right), 5.34(\mathrm{~s}$, $\left.2 \mathrm{H},-\mathrm{CH}_{2}-\mathrm{N}\right), 5.10-5.20\left(\mathrm{~m}, 4 \mathrm{H},-\mathrm{CH}=\mathrm{CH}_{2}\right), 3.56\left(\mathrm{~d}, \mathrm{~J}=6.8 \mathrm{~Hz}, 2 \mathrm{H},-\mathrm{CH}_{2}-\mathrm{CH}=\mathrm{CH}_{2}\right), 3.44(\mathrm{~d}$, $\left.J=6.8 \mathrm{~Hz}, 2 \mathrm{H},-\mathrm{CH}_{2}-\mathrm{CH}=\mathrm{CH}_{2}\right) ;{ }^{13} \mathrm{C} \mathrm{NMR}\left(100 \mathrm{MHz} \mathrm{CDCl}_{3}\right) \delta: 165.19,165.16,162.81(\mathrm{~d}$, $\left.J_{C F}=252.0 \mathrm{~Hz}\right), 160.57,160.53,153.94,153.89,138.04,137.48,136.55,134.37,131.20,131.09$, $131.07,131.01,130.99,130.49,130.08,124.98,124.89,124.62,123.70,123.63,123.42,122.99$, $122.96,119.54,119.49,119.33,119.27,117.40,116.88,114.36,114.12,108.20,106.91,40.08$, 36.89, 36.82, 33.34; HRMS: calcd for $\mathrm{C}_{38} \mathrm{H}_{27} \mathrm{~F}_{2} \mathrm{~N}_{6} \mathrm{O}_{6}\left([\mathrm{M}+\mathrm{H}]^{+}\right)$701.1882, found 701.1959.

Data for 6j: White solid, yield: $50 \%$, m.p. $168-170{ }^{\circ} \mathrm{C}$; IR cm ${ }^{-1}(\mathrm{KBr}): 3074,2970,1778$, $1611,1499,1442,1237 ;{ }^{1} \mathrm{H}$ NMR $\left(400 \mathrm{MHz} \mathrm{CDCl}_{3}\right) \delta: 8.01-8.05(\mathrm{~m}, 4 \mathrm{H},-\mathrm{Ph}), 7.30-7.32(\mathrm{~m}$, $2 \mathrm{H},-\mathrm{Ph}), 7.15-7.20(\mathrm{~m}, 4 \mathrm{H},-\mathrm{Ph}), 7.04(\mathrm{~s}, 1 \mathrm{H},-\mathrm{Ph}), 6.97(\mathrm{~d}, J=1.2 \mathrm{~Hz}, 1 \mathrm{H},-\mathrm{Ph}), 5.90-6.02(\mathrm{~m}$, $\left.2 \mathrm{H},-\mathrm{C} \underline{H}=\mathrm{CH}_{2}\right), 5.37\left(\mathrm{~s}, 2 \mathrm{H},-\mathrm{C}_{2}-\mathrm{N}\right), 5.33\left(\mathrm{~s}, 2 \mathrm{H},-\mathrm{C}_{2}-\mathrm{N}\right), 5.10-5.20\left(\mathrm{~m}, 4 \mathrm{H},-\mathrm{CH}=\mathrm{CH}_{2}\right)$, $3.56\left(\mathrm{~d}, J=6.8 \mathrm{~Hz}, 2 \mathrm{H},-\mathrm{CH}_{2}-\mathrm{CH}=\mathrm{CH}_{2}\right), 3.43\left(\mathrm{~d}, J=6.8 \mathrm{~Hz}, 2 \mathrm{H},-\mathrm{CH}_{2}-\mathrm{CH}=\mathrm{CH}_{2}\right) ;{ }^{13} \mathrm{C} \mathrm{NMR}$ $\left(100 \mathrm{MHz} \mathrm{CDCl}_{3}\right) \delta: 165.37,165.34,165.14\left(\mathrm{~d}, J_{\mathrm{CF}}=255.0 \mathrm{~Hz}\right), 160.23,160.22,153.94,153.91$, $140.80,138.01,137.42,136.54,134.36,131.20,130.50,130.10,129.62,129.52,129.51,124.60$, 123.67, 123.63, 123.41, 119.44, 119.41, 117.39, 116.84, 116.66, 116.65, 116.44, 116.43, 108.22, 106.90, 40.07, 36.88, 36.83, 33.33; HRMS: calcd for $\mathrm{C}_{38} \mathrm{H}_{27} \mathrm{~F}_{2} \mathrm{~N}_{6} \mathrm{O}_{6}\left([\mathrm{M}+\mathrm{H}]^{+}\right)$701.1882, found 701.1951.

Data for 6k: White solid, yield: $64 \%$, m.p. $181-184^{\circ} \mathrm{C}$; IR cm ${ }^{-1}(\mathrm{KBr}): 2923,1780,1440$, 1341, 1064, 730; ${ }^{1} \mathrm{H}$ NMR $\left(400 \mathrm{MHz} \mathrm{CDCl}_{3}\right) \delta: 7.87(\mathrm{~d}, J=7.6 \mathrm{~Hz}, 2 \mathrm{H},-\mathrm{Ph}), 7.37-7.43(\mathrm{~m}$, $2 \mathrm{H},-\mathrm{Ph}), 7.28-7.33(\mathrm{~m}, 6 \mathrm{H},-\mathrm{Ph}), 7.04(\mathrm{~d}, J=1.2 \mathrm{~Hz}, 1 \mathrm{H},-\mathrm{Ph}), 6.98(\mathrm{~d}, J=1.2 \mathrm{~Hz}, 1 \mathrm{H},-\mathrm{Ph})$, 5.90-6.00 (m, 2H, $\left.-\mathrm{C} \underline{H}=\mathrm{CH}_{2}\right), 5.39\left(\mathrm{~s}, 2 \mathrm{H},-\mathrm{CH}_{2}-\mathrm{N}\right), 5.34\left(\mathrm{~s}, 2 \mathrm{H},-\mathrm{CH}_{2}-\mathrm{N}\right), 5.09-5.20(\mathrm{~m}, 4 \mathrm{H}$, $\left.-\mathrm{CH}=\mathrm{CH}_{2}\right), 3.56\left(\mathrm{~d}, J=6.8 \mathrm{~Hz}, 2 \mathrm{H},-\mathrm{CH}_{2}-\mathrm{CH}=\mathrm{CH}_{2}\right), 3.43\left(\mathrm{~d}, J=6.8 \mathrm{~Hz}, 2 \mathrm{H},-\underline{\mathrm{C}}_{2}-\mathrm{CH}=\mathrm{CH}_{2}\right)$, $2.67\left(\mathrm{~s}, \overline{3 \mathrm{H}},-\mathrm{CH}_{3}\right), 2.62\left(\mathrm{~s}, 3 \mathrm{H},-\mathrm{C}_{\underline{3}}\right) ;{ }^{1 \overline{3}} \mathrm{C} \mathrm{NMR}\left(100 \mathrm{MHz} \mathrm{CDCl}_{3}\right) \delta: 166.33,166.28,159.74$, $159.71,153.98,153.94,140.80,138.72,138.03,137.35,136.56,134.39,131.84,131.81,131.73$, $131.69,131.20,130.56,130.16,129.18,126.25,124.59,123.62,123.60,123.38,122.16,117.34$, 116.82, 108.20, 106.88, 40.07, 36.90, 36.85, 33.33, 22.09, 22.06; HRMS: calcd for $\mathrm{C}_{40} \mathrm{H}_{33} \mathrm{~N}_{6} \mathrm{O}_{6}$ $\left([\mathrm{M}+\mathrm{H}]^{+}\right)$693.2383, found 693.2457.

Data for 61: White solid, yield: $20 \%$, m.p. $150-153^{\circ} \mathrm{C}$; IR cm ${ }^{-1}(\mathrm{KBr}): 2924,1781,1441$, 1340, 1064, 724; ${ }^{1} \mathrm{H}$ NMR $\left(400 \mathrm{MHz} \mathrm{CDCl}_{3}\right) \delta: 7.79-7.85(\mathrm{~m}, 4 \mathrm{H},-\mathrm{Ph}), 7.31-7.37(\mathrm{~m}, 6 \mathrm{H}$, $-\mathrm{Ph}), 7.03(\mathrm{~d}, J=1.6 \mathrm{~Hz}, 1 \mathrm{H},-\mathrm{Ph}), 6.97(\mathrm{~d}, J=1.2 \mathrm{~Hz}, 1 \mathrm{H},-\mathrm{Ph}), 5.90-6.02\left(\mathrm{~m}, 2 \mathrm{H},-\mathrm{CH}=\mathrm{CH}_{2}\right)$, $5.38\left(\mathrm{~s}, 2 \mathrm{H},-\mathrm{CH}_{2}-\mathrm{N}\right), 5.33\left(\mathrm{~s}, 2 \mathrm{H},-\mathrm{C}_{2}-\mathrm{N}\right), 5.09-5.20\left(\mathrm{~m}, 4 \mathrm{H},-\mathrm{CH}=\mathrm{CH}_{2}\right), 3.56(\mathrm{~d}, J=6.4 \mathrm{~Hz}$, 
$\left.2 \mathrm{H},-\mathrm{CH}_{2}-\mathrm{CH}=\mathrm{CH}_{2}\right), 3.43\left(\mathrm{~d}, \mathrm{~J}=6.8 \mathrm{~Hz}, 2 \mathrm{H},-\mathrm{CH}_{2}-\mathrm{CH}=\mathrm{CH}_{2}\right), 2.41\left(\mathrm{~s}, 3 \mathrm{H},-\mathrm{CH}_{3}\right), 2.38(\mathrm{~s}, 3 \mathrm{H}$, $\left.-\underline{H}_{3}\right) ;{ }^{13} \mathrm{C} \mathrm{NMR}\left(100 \mathrm{MHz} \mathrm{CDCl}_{3}\right) \delta: 166.35,166.29,160.11,160.08,153.98,153.95,140.78$, $139.08,139.04,138.01,137.38,136.54,134.39$, 133.11, 133.06, 131.22, 130.51, 130.12, 129.01, $127.63,124.63,124.33,123.60,123.39,122.94,117.35,116.83,108.23,106.89,40.06,36.93,36.87$, 33.33, 21.29, 21.27; HRMS: calcd for $\mathrm{C}_{40} \mathrm{H}_{33} \mathrm{~N}_{6} \mathrm{O}_{6}\left([\mathrm{M}+\mathrm{H}]^{+}\right)$693.2383, found 693.2445.

Data for 6m: White solid, yield: $32 \%$, m.p. $212-215^{\circ} \mathrm{C}$; $\mathrm{IR} \mathrm{cm}^{-1}(\mathrm{KBr}): 2922,1776$, $1615,1499,1443,1343 ;{ }^{1} \mathrm{H}$ NMR $\left(400 \mathrm{MHz} \mathrm{CDCl}_{3}\right) \delta: 7.88-7.92(\mathrm{~m}, 4 \mathrm{H},-\mathrm{Ph}), 7.28-7.31(\mathrm{~m}$, $6 \mathrm{H},-\mathrm{Ph}), 7.03(\mathrm{~s}, 1 \mathrm{H},-\mathrm{Ph}), 6.97(\mathrm{~d}, J=0.8 \mathrm{~Hz}, 1 \mathrm{H},-\mathrm{Ph}), 5.90-6.02\left(\mathrm{~m}, 2 \mathrm{H},-\mathrm{C} \underline{H}=\mathrm{CH}_{2}\right), 5.37$ $\left(\mathrm{s}, 2 \mathrm{H},-\mathrm{CH}_{2}-\mathrm{N}\right), 5.32\left(\mathrm{~s}, 2 \mathrm{H},-\mathrm{CH}_{2}-\mathrm{N}\right), 5.09-5.20\left(\mathrm{~m}, 4 \mathrm{H},-\mathrm{CH}=\mathrm{CH}_{2}\right), 3.56(\mathrm{~d}, J=6.4 \mathrm{~Hz}, 2 \mathrm{H}$, $\left.-\mathrm{C}_{2}-\mathrm{CH}=\mathrm{CH}_{2}\right), 3.43\left(\mathrm{~d}, \mathrm{~J}=6.8 \mathrm{~Hz}, 2 \mathrm{H},-\mathrm{CH}_{2}-\mathrm{CH}=\mathrm{CH}_{2}\right), 2.41\left(\mathrm{~s}, 3 \mathrm{H},-\mathrm{CH}_{3}\right), 2.40(\mathrm{~s}, 3 \mathrm{H}$, $\left.-\mathrm{CH}_{3}\right)$; HRMS: calcd for $\mathrm{C}_{40} \mathrm{H}_{33} \mathrm{~N}_{6} \mathrm{O}_{6}\left([\mathrm{M}+\mathrm{H}]^{+}\right)$693.2383, found 693.2455.

Data for 6n: White solid, yield: $64 \%$, m.p. $95-98^{\circ} \mathrm{C}$; IR cm ${ }^{-1}(\mathrm{KBr}): 2926,1783,1607$, $1445,1261,1014,749 ;{ }^{1} \mathrm{H}$ NMR $\left(400 \mathrm{MHz} \mathrm{CDCl}_{3}\right) \delta: 7.86-7.89(\mathrm{~m}, 2 \mathrm{H},-\mathrm{Ph}), 7.45-7.52(\mathrm{~m}, 2 \mathrm{H}$, $-\mathrm{Ph}), 7.28-7.31(\mathrm{~m}, 2 \mathrm{H},-\mathrm{Ph}), 6.96-7.04(\mathrm{~m}, 6 \mathrm{H},-\mathrm{Ph}), 5.89-6.02\left(\mathrm{~m}, 2 \mathrm{H},-\mathrm{C} \underline{H}=\mathrm{CH}_{2}\right), 5.38(\mathrm{~s}, 2 \mathrm{H}$, $\left.-\underline{\mathrm{H}}_{2}-\mathrm{N}\right), 5.34\left(\mathrm{~s}, 2 \mathrm{H},-\mathrm{C}_{2}-\mathrm{N}\right), 5.08-5.19\left(\mathrm{~m}, 4 \mathrm{H},-\mathrm{CH}=\mathrm{CH}_{2}\right), 3.91\left(\mathrm{~s}, 3 \mathrm{H},-\mathrm{OCH}_{3}\right), 3.83(\mathrm{~s}, 3 \mathrm{H}$,

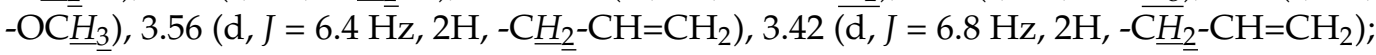
${ }^{13} \mathrm{C}$ NMR $\left(100 \mathrm{MHz} \mathrm{CDCl}_{3}\right) \delta: 164.85,159.88,158.02,157.96,153.98,140.78,138.02,137.29$, $136.57,134.44,133.59,133.54,131.20,130.63,130.60,130.24,124.57,123.58,123.46,123.32$, $120.77,117.30,116.78,112.23,111.97,111.91,108.32,106.95,55.98,55.87,40.06,36.99,36.94$, 33.33; HRMS: calcd for $\mathrm{C}_{40} \mathrm{H}_{33} \mathrm{~N}_{6} \mathrm{O}_{8}\left([\mathrm{M}+\mathrm{H}]^{+}\right)$725.2282, found 725.2355.

Data for 6o: White solid, yield: $83 \%$, m.p. $100-103^{\circ} \mathrm{C}$; IR cm ${ }^{-1}(\mathrm{KBr}): 2963,1782,1465$, 1143,$1045 ;{ }^{1} \mathrm{H}$ NMR $\left(400 \mathrm{MHz} \mathrm{CDCl}_{3}\right) \delta: 7.52-7.58(\mathrm{~m}, 4 \mathrm{H},-\mathrm{Ph}), 7.35-7.41(\mathrm{~m}, 2 \mathrm{H},-\mathrm{Ph})$, $7.31(\mathrm{~d}, J=0.8 \mathrm{~Hz}, 2 \mathrm{H},-\mathrm{Ph}), 7.03-7.07(\mathrm{~m}, 3 \mathrm{H},-\mathrm{Ph}), 6.97(\mathrm{~d}, J=1.2 \mathrm{~Hz}, 1 \mathrm{H},-\mathrm{Ph}), 5.94-6.00$ $\left(\mathrm{m}, 2 \mathrm{H},-\mathrm{C} \underline{\mathrm{H}}=\mathrm{CH}_{2}\right), 5.38\left(\mathrm{~s}, 2 \mathrm{H},-\mathrm{C}_{2}-\mathrm{N}\right), 5.33\left(\mathrm{~s}, 2 \mathrm{H},-\mathrm{C}_{2}-\mathrm{N}\right), 5.09-5.20\left(\mathrm{~m}, 4 \mathrm{H},-\mathrm{CH}=\mathrm{CH}_{2}\right)$, $3.86\left(\mathrm{~s}, 3 \mathrm{H},-\mathrm{OCH} \mathrm{H}_{3}\right), 3.83\left(\mathrm{~s}, 3 \mathrm{H},-\mathrm{OC} \underline{H}_{3}\right), 3.56\left(\mathrm{~d}, J=6.8 \mathrm{~Hz}, 2 \mathrm{H},-\mathrm{C}_{2}-\mathrm{CH}=\mathrm{CH}_{2}\right), 3.43(\overline{\mathrm{d}}, J$ $\left.=6.4 \mathrm{~Hz}, 2 \mathrm{H},-\mathrm{CH}_{2}-\mathrm{CH}=\mathrm{CH}_{2}\right) ;{ }^{13} \mathrm{C} \mathrm{NMR}\left(100 \mathrm{MHz} \mathrm{CDCl}_{3}\right) \delta: 166.13,166.08,160.23,160.20$, $159.99,159.95,153.95,140.79,138.01,137.38,136.54,134.38,131.21,130.52,130.29,130.13$, 124.63, 124.16, 123.61, 123.39, 119.58, 118.84, 118.80, 117.36, 116.84, 111.70, 111.61, 108.22, 106.89, 55.53, 40.06, 36.94, 36.88, 33.33; HRMS: calcd for $\mathrm{C}_{40} \mathrm{H}_{33} \mathrm{~N}_{6} \mathrm{O}_{8}\left([\mathrm{M}+\mathrm{H}]^{+}\right) 725.2282$, found 725.2354 .

Data for 6p: White solid, yield: $50 \%$, m.p. $228-230{ }^{\circ} \mathrm{C}$; IR cm ${ }^{-1}(\mathrm{KBr}): 2928,1774$, 1612, 1498, 1262, 1175; ${ }^{1} \mathrm{H}$ NMR $\left(400 \mathrm{MHz}^{\circ} \mathrm{CDCl}_{3}\right) \delta: 7.93-7.97(\mathrm{~m}, 4 \mathrm{H},-\mathrm{Ph}), 7.30(\mathrm{~s}, 2 \mathrm{H}$, $-\mathrm{Ph}), 7.03(\mathrm{~s}, 1 \mathrm{H},-\mathrm{Ph}), 6.95-6.99(\mathrm{~m}, 5 \mathrm{H},-\mathrm{Ph}), 5.90-6.00\left(\mathrm{~m}, 2 \mathrm{H},-\mathrm{C} \underline{H}=\mathrm{CH}_{2}\right), 5.36(\mathrm{~s}, 2 \mathrm{H}$, $\left.-\mathrm{C}_{2}-\mathrm{N}\right), 5.31\left(\mathrm{~s}, 2 \mathrm{H},-\mathrm{C}_{2}-\mathrm{N}\right), 5.09-5.20\left(\mathrm{~m}, 4 \mathrm{H},-\mathrm{CH}=\mathrm{CH}_{2}\right), 3.86\left(\mathrm{~s}, 3 \mathrm{H},-\mathrm{OCH}_{3}\right), 3.85(\mathrm{~s}, 3 \mathrm{H}$, $\left.\left.-\mathrm{OC} \underline{H}_{3}\right), 3.56\left(\mathrm{~d}, J=6.4 \mathrm{~Hz}, 2 \mathrm{H},-\mathrm{CH}_{2}-\mathrm{CH}=\mathrm{CH}_{2}\right), 3.43 \overline{(\mathrm{d}}, J=6.4 \mathrm{~Hz}, 2 \mathrm{H},-\overline{\mathrm{CH}}_{2}-\mathrm{CH}=\mathrm{CH}_{2}\right)$; ${ }^{13} \mathrm{C}$ NMR $\left(100 \mathrm{MHz} \mathrm{CDCl}_{3}\right) \delta: 166.12,166.07,162.74,162.71,159.66,159.63,153.95,140.77$, $138.01,137.35,136.57,134.40,131.22,130.54,130.15,128.99,124.59,123.54,123.36,117.33$, $116.80,115.54,114.55,108.26,106.91,55.48,40.06,36.87,33.33$; HRMS: calcd for $\mathrm{C}_{40} \mathrm{H}_{33} \mathrm{~N}_{6} \mathrm{O}_{8}$ $\left([\mathrm{M}+\mathrm{H}]^{+}\right) 725.2282$, found 725.2358 .

\subsection{Cell Culture}

HEK-293T cells were purchased from the American Type Culture Collection (ATCC, Rockville, MD, USA). HEK-293T-ACE2 ${ }^{\text {h }}$ cells were constructed by Sino Biological (Beijing, China). All the cell lines were cultured in Dulbecco Modified Eagle Medium (DMEM) supplemented with $10 \%$ fetal bovine serum, the antibiotics penicillin $(50 \mathrm{U} / \mathrm{mL})$ and streptomycin $\left(50 \mu \mathrm{g} / \mathrm{mL}\right.$, Invitrogen, Paisley, Scotland, UK) at $37{ }^{\circ} \mathrm{C}$ in a humidified atmosphere of $5 \% \mathrm{CO}_{2}$. Besides, $100 \mu \mathrm{g} / \mathrm{mL}$ hygromycin was used for the culture of HEK-293T-ACE2 ${ }^{\mathrm{h}}$ cells.

\subsection{Cytotoxicity Assay}

The cytotoxic effect of honokiol derivatives on HEK-293T-ACE2 ${ }^{\mathrm{h}}$ cells was evaluated by MTT assay. HEK-293T-ACE $2^{\mathrm{h}}$ cells were seed into 96-well plate at a density of $1 \times 10^{4}$ cells per well and then treated with various concentrations of compounds for either 4 or $48 \mathrm{~h}$. Then $10 \mu \mathrm{L}$ of 3-(4, 5-dimethylthiazol-2-yl)-2, 5-diphenyltetrazolium bromide 
(MTT) $(5 \mathrm{mg} / \mathrm{mL})$ solution was added to each well for another $4 \mathrm{~h}$ incubation. The supernatants were then removed, and the formed formazan crystals were dissolved in $100 \mu \mathrm{L}$ DMSO and the plate was agitated for $10 \mathrm{~min}$. Relative cell viability was assessed by measuring the absorbance at $570 \mathrm{~nm}$ by using a microplate reader (Infinite M200 PRO Microplate Reader, Tecan, Swiss). The survival rate of HEK-293T-ACE2 ${ }^{\mathrm{h}}$ cells was calculated using the following formula: $\left[\left(\mathrm{OD}_{\text {treated }}-\mathrm{OD}_{\text {blank }}\right) /\left(\mathrm{OD}_{\text {control }}-\mathrm{OD}_{\text {blank }}\right)\right] \times 100 \%$. The $50 \%$ toxic concentration $\left(\mathrm{TC}_{50}\right)$ for $48 \mathrm{~h}$ was calculated by the GraphPad Prism 8.0 software (La Jolla, $\mathrm{CA}, \mathrm{USA})$. The maximum nontoxic concentration $\left(\mathrm{CC}_{0}\right)$ for $4 \mathrm{~h}$ was determined as the maximum tested concentration in which the cell viability was $100 \%$. Data were obtained from three independent experiments.

\subsection{Production of SARS-CoV-2 Spike Pseudoviruses}

HIV-1 reporter pseudoviruses expressing SARS-CoV-2 spike protein and luciferase were constructed by using pNL4-3.Luc.R-E- plasmid and pcDNA3.1-SARS-CoV-2-SpikeMyc plasmid [14-16]. The plasmid of pNL4-3.Luc.R-E- was bought from the NIH AIDS repository. The plasmid of pcDNA3.1-SARS-CoV-2-Spike-Myc was purchased from Beyotime (Shanghai, China). HEK-293T cells were seeded into six-well plates at a density of $5 \times 10^{5}$ cells per well. When the cells' confluency reached $60-80 \%$ after $24 \mathrm{~h}$ incubation, two plasmids of pNL4-3.Luc.R-E- and pcDNA3.1-SARS-CoV-2-Spike-Myc were co-transfected into the cells with $125 \mu \mathrm{L}$ of Opti-MEM and $6 \mu \mathrm{L}$ of Lipo8000 reagent (Beyotime, China). After $24 \mathrm{~h}$ post-transfection, supernatants were harvested and then centrifuged at $1500 \mathrm{rpm} / \mathrm{min}$ to remove cell debris. The infectious competency of $30 \mu \mathrm{L}$ of produced pseudovirus to host cells was measured with reference to that of SARS-CoV-2 spike pseudovirus $\left(10^{10}\right.$ copies / $\mathrm{mL}$, PSV001) from Sino Biological as follows. A series of $0,5,10,20$ and $50 \mu \mathrm{L}$ of SARS-CoV-2 spike pseudovirus $\left(10^{10}\right.$ copies $/ \mathrm{mL}$ ) from Sino Biological was diluted by culture medium to a final volume of $100 \mu \mathrm{L}$, and subsequently utilized to infect the HEK-293T-ACE2 ${ }^{\mathrm{h}}$ cells for $2 \mathrm{~h}$ at $37^{\circ} \mathrm{C}$ in duplicates. After that, the cells were replaced with the fresh culture medium to remove the inoculum and were further incubated for $48 \mathrm{~h}$. Subsequently, $100 \mu \mathrm{L}$ of cell lysate buffer was added into each well, and the plate was gently agitated for $10 \mathrm{~min}$. The luciferase luminescence was measured at $578 \mathrm{~nm}$ by a microplate reader (SpectraMax iD5 Multi-Mode Microplate Reader, Molecular Devices, San Jose, CA, USA) immediately after $100 \mu \mathrm{L}$ of luminescence solution was added into each well according to the instruction from the Firefly Luciferase Reporter Gene Assay Kit (Beyotime, Shanghai, China). A standard curve of luciferase luminescence in response to pseudovirus copies was generated as the viral infection equation, $\mathrm{Y}=197.17 \mathrm{x}-62.821$, with regression coefficient $R^{2}$ value of 0.9996 [28]. Simultaneously, the $30 \mu \mathrm{L}$ supernatant of produced pseudovirus was used to infect the host cells following the above experimental procedure in hexaplicates. From the established standard curve, the infectious competency of $30 \mathrm{uL}$ supernatant solution of produced pseudovirus was determined as equivalent to that of $9.12 \pm 0.88 \times 10^{7}$ copies $(n=6)$ of SARS-CoV-2 pseudovirus from Sino Biological. Thus, the pseudovirus utilized in our experiments was considered to possess equivalent infectious competency to $9.12 \pm 0.88 \times 10^{7}$ copies of SARS-CoV-2 pseudovirus from Sino Biological for HEK-293T-ACE $2^{\mathrm{h}}$ cells under tested conditions. The quantified pseudovirus made in our lab was thus utilized for the subsequent infection experiments to HEK-293T-ACE2 ${ }^{\mathrm{h}}$ cells.

\subsection{The Detection of SARS-CoV-2 Spike Pseudovirus Entry into HEK-293T-ACE2 ${ }^{h}$ Cells}

The tested compounds were used at concentrations ranging from 1.56 to $100 \mu \mathrm{M}$ at two-fold serial dilutions. An antibody of SARS-CoV-2 (Sino Biological, Beijing, China) was employed as a positive viral entry inhibitor with tested concentrations ranging from 1.875 to $60 \mathrm{nM}$. HEK-293T-ACE2 ${ }^{\text {h }}$ cells $\left(1 \times 10^{4}\right.$ in 100 uL DMEM) were seeded in 96-well plates, and cultured in a $37^{\circ} \mathrm{C}$ incubator containing $5 \% \mathrm{CO}_{2}$ for $24 \mathrm{~h}$. Then, the culture medium was replaced by $100 \mathrm{uL}$ compounds-containing DMEM medium for $2 \mathrm{~h}$ incubation in the $37^{\circ} \mathrm{C}$ incubator. After $2 \mathrm{~h}$ incubation, $30 \mu \mathrm{L}$ pseudovirus (MOI $=100$ virus 
particles/cell), $20 \mu \mathrm{L}$ media, and $50 \mu \mathrm{L}$ two-fold concentration of compounds were simultaneously added into each well for another $2 \mathrm{~h}$ incubation at $37^{\circ} \mathrm{C}$. After removal of the inoculum, cells were overlaid with $100 \mu \mathrm{L}$ fresh DMEM, and incubated continuously at $37^{\circ} \mathrm{C}$ for $48 \mathrm{~h}$. The culture medium was aspirated and the cells were washed once by PBS. Then, $100 \mu \mathrm{L}$ of cell lysate buffer was added into each well, and the plate was agitated for $10 \mathrm{~min}$. The cell lysate was completely transferred to an opaque 96-well white solid plate. The luciferase luminescence was measured at $578 \mathrm{~nm}$ by a microplate reader (SpectraMax iD5 Multi-Mode Microplate Reader, Molecular Devices, San Jose, CA, USA) immediately after $100 \mu \mathrm{L}$ of luminescence solution was added into each well according to the instruction from the Firefly Luciferase Reporter Gene Assay Kit (Beyotime, Shanghai, China). HEK-293T-ACE $2^{\mathrm{h}}$ cells infected only with SARS-CoV-2 spike pseudovirus were considered as control group, and the luciferase luminescence value of the control was defined as 100\%. The values of luminescence of compounds-treated groups were normalized accordingly [29]. A standard curve was simultaneously carried out by using SARS-CoV-2 pseudovirus $\left(1 \times 10^{10}\right.$ copies $/ \mathrm{mL}$ from Sino Biological $)$ to infect HEK-293T-ACE $2^{\mathrm{h}}$ cells in each independent experiment. The inhibitory activity of tested compounds against pseudovirus entry was expressed as $\mathrm{IC}_{50}$ value which was defined as the concentration that inhibits $50 \%$ of the pseudovirus from entering the target cell. The $\mathrm{IC}_{50}$ was calculated by using the GraphPad Prism 8.0 software (La Jolla, CA, USA). All the data were expressed as means \pm standard deviation (SD) from three independent experiments.

\subsection{Biolayer Interferometry (BLI) Binding Assay}

The binding kinetics of compounds with the protein of recombinant histidine-tagged human ACE2 (Sino Biological, Beijing, China) were analyzed by bio-layer interferometry on an Octet system (Octet RED96, ForteBio, Fremont, CA, USA) [22,23]. Histidine-tagged human ACE2 protein $(25 \mu \mathrm{g} / \mathrm{mL}$ aqueous solution) was immobilized on a nickel charged nitrilotriacetic acid (Ni-NTA) biosensor (Fortebi, Fremont, CA, USA) by a protein-loading program of the instrument. Each stock solution of compounds (10 mM in DMSO) was serially diluted by PBS buffer with a final DMSO concentration of $1.0 \%$. The SARS-CoV-2 spike RBD protein (Sino Biological, Beijing, China) was utilized as a positive binding protein with tested concentrations ranging from 0.03125 to $1 \mathrm{nM}$. Both protein-immobilized and empty biosensors were equilibrated in PBS buffer for $10 \mathrm{~min}$ at room temperature before preceding data acquisition, and all experiments were performed at $30{ }^{\circ} \mathrm{C}$. Both the protein-coated and empty biosensors were dipped in wells containing serially diluted samples. The signal of background was subtracted from all samples by dipping a proteinimmobilized biosensor in the blank buffer. Under the same conditions, empty biosensors were also dipped in serially diluted samples for reference subtraction. The subtracted sensorgrams were then fitted to a 1:1 binding model by using Octet Data Analysis Software v11.1 (ForteBio, Torrance, CA, USA) to calculate the resulting equilibrium dissociation constant $\left(\mathrm{K}_{\mathrm{D}}\right)$ values for the interaction. The interaction of $\mathbf{6} \mathbf{p}$ with a recombinant histidinetagged SARS-CoV-2 spike RBD protein $(25 \mu \mathrm{g} / \mathrm{mL}$ aqueous solution, Sino Biological, Beijing, China) was also analyzed with the same experimental procedure by BLI binding assay.

\subsection{Docking Studies}

CDOCKER of Discovery Studio software was employed to perform molecular docking analysis on the structure of protein of human ACE2 bound with its inhibitor (PDB ID: 1R4L). A docking pocket was generated based on the position of the inhibitor of human ACE2 [27]. The binding modes were analyzed with the Discovery Studio software.

\subsection{ELISA Assay}

An ELISA assay that mimics the viral spike RBD-ACE2 binding process was employed to investigate the compounds' interventive effect on the binding of spike RBD-ACE2 by a SARS-CoV-2 (2019-nCoV) inhibitor screening ELISA kit (Sino Biological, Beijing, China) 
with a slight optimization of the kit's experimental protocol. Briefly, the wells pre-coated with SARS-CoV-2 spike RBD-mFc recombinant protein were washed three times with washing buffer $(300 \mu \mathrm{L} /$ well). At the same time, human ACE2 protein with His Tag $(100 \mu \mathrm{L})$ was incubated with equal volume of compounds for $1 \mathrm{~h}$. The final concentration of tested compounds was $12.5,25$, and $50 \mu \mathrm{M}$ in the mixture solution, respectively. The mixture of compounds-incubated ACE2 solution $(200 \mu \mathrm{L})$ was added into each well for another $1 \mathrm{~h}$ incubation. Then, the solution in wells was disposed and the wells were washed three times. Anti-His Tag antibody (HRP, $100 \mu \mathrm{L}$ ) was added into each well for $1 \mathrm{~h}$ incubation at room temperature. Subsequently, each well was washed three times again, and substrate solution $(200 \mu \mathrm{L})$ was added into each well for 15 minutes incubation with protection from light. Finally, the optical density of each well was measured at $450 \mathrm{~nm}$ by a microplate reader after the stop solution $(50 \mu \mathrm{L})$ was supplemented to each well. The average OD value of wells with only human ACE2 protein was defined as the control group with the assumption that the pre-coated spike RBD was completely occupied by human ACE2 protein. The inhibitory rate (IR) of compound was calculated as follows: $\operatorname{IR}(\%)=\left(\mathrm{OD}_{\text {control }}-\mathrm{OD}_{\text {compound-treated }}\right) / \mathrm{OD}_{\text {control }} \times 100$. The SARS-CoV-2 antibody inhibitor was provided by the ELISA kit, and its $\mathrm{IC}_{50}$ value was measured to be $2.59 \mathrm{nM}$ in this assay. All the data were from three independent experiments.

\subsection{Statistical Analysis}

Statistical comparisons were calculated by Student's t-test analysis. $p<0.05$ was regarded as statistically significant.

\section{Conclusions}

In summary, sixteen derivatives of honokiol have been successfully synthesized. Compounds $6 \mathbf{p}$ showed the most potent antiviral entry activity as a human ACE2 blocker. Moreover, $\mathbf{6 a}$ and $\mathbf{6 p}$ had higher biological safety for the host cells than the parental honokiol. This was the first report about the antiviral entry activity of modified honokiol derivative $6 p$ against SARS-CoV-2 pseudovirus via targeting human ACE2 receptor. The inhibitory effect of $\mathbf{6} \mathbf{p}$ on SARS-CoV-2 viral strains needs further study in a biosafety level 3 facility. This research may contribute to the discovery of potential viral entrance inhibitors for SARS-CoV-2 virus.

Supplementary Materials: The following are available online at https:/ /www.mdpi.com/article/10 $.3390 / \mathrm{ph} 14090885 / \mathrm{s} 1$. Figures S1-S47: HRMS,${ }^{1} \mathrm{H}$, and ${ }^{13} \mathrm{C}$ NMR spectra for compounds 6a-p.

Author Contributions: Conceptualization, L.-P.B. and Z.-H.J.; methodology, Y.G., J.-R.M. and L.-P.B.; software, J.-Z.L.; validation, T.X. and Z.-Y.Z.; formal analysis, Y.G., J.-R.M. and J.-Z.L.; investigation, Y.G. and J.-R.M.; resources, L.-P.B.; data curation, Y.G. and L.-P.B.; writing-original draft preparation, Y.G., J.-R.M. and J.-Z.L.; writing—review and editing, L.-P.B. and Z.-H.J.; visualization, J.-R.M.; supervision, L.-P.B. and Y.G.; project administration, L.-P.B.; funding acquisition, L.-P.B. and Z.-H.J. All authors have read and agreed to the published version of the manuscript.

Funding: This research was financially supported by The Science and Technology Development Fund, Macau SAR (File no. 0065/2020/A2, 0074/2019/AMJ, 0043/2020/AGJ and 0064/2020/A). This work was also supported by the Emergency Key Program of Guangzhou Laboratory (Grant No. EKPG21-06).

Institutional Review Board Statement: Not applicable.

Informed Consent Statement: Not applicable.

Data Availability Statement: The data presented in this study are available on request from the corresponding author.

Acknowledgments: All the authors thank the Department of Science and Technology of Guangdong Province for the support of Guangdong-Hong Kong-Macao Joint Laboratory of Respiratory Infectious Disease. 
Conflicts of Interest: The authors declare no conflict of interest.

\section{References}

1. Gao, J.; Ding, Y.; Wang, Y.; Liang, P.; Zhang, L.; Liu, R. Oroxylin A is a severe acute respiratory syndrome coronavirus 2spiked pseudotyped virus blocker obtained from Radix Scutellariae using angiotensin-converting enzyme II/cell membrane chromatography. Phytother. Res. 2021, 35, 3194-3204. [CrossRef]

2. Chen, J.; Li, S.; Lei, Z.; Tang, Q.; Mo, L.; Zhao, X.; Xie, F.; Zi, D.; Tan, J. Inhibition of SARS-CoV-2 pseudovirus invasion by ACE2 protecting and Spike neutralizing peptides: An alternative approach to COVID19 prevention and therapy. Int. J. Biol. Sci. 2021, 17, 2957. [CrossRef]

3. Ge, S.; Wang, X.; Hou, Y.; Lv, Y.; Wang, C.; He, H. Repositioning of histamine H1 receptor antagonist: Doxepin inhibits viropexis of SARS-CoV-2 Spike pseudovirus by blocking ACE2. Eur. J. Pharmacol. 2021, 896, 173897. [CrossRef]

4. Zhang, Y.; Hu, S.; Wang, J.; Xue, Z.; Wang, C.; Wang, N. Dexamethasone inhibits SARS-CoV-2 spike pseudotyped virus viropexis by binding to ACE2. Virology 2021, 554, 83-88. [CrossRef] [PubMed]

5. Luo, E.; Zhang, D.; Luo, H.; Liu, B.; Zhao, K.; Zhao, Y.; Bian, Y.; Wang, Y. Treatment efficacy analysis of traditional Chinese medicine for novel coronavirus pneumonia (COVID-19): An empirical study from Wuhan, Hubei Province, China. Chin. Med. 2020, 15, 1-13. [CrossRef]

6. Ruan, X.; Du, P.; Zhao, K.; Huang, J.; Xia, H.; Dai, D.; Huang, S.; Cui, X.; Liu, L.; Zhang, J. Mechanism of Dayuanyin in the treatment of coronavirus disease 2019 based on network pharmacology and molecular docking. Chin. Med. 2020, 15, 1-17. [CrossRef] [PubMed]

7. Xiao, M.; Tian, J.; Zhou, Y.; Xu, X.; Min, X.; Lv, Y.; Peng, M.; Zhang, Y.; Yan, D.; Lang, S. Efficacy of Huoxiang Zhengqi dropping pills and Lianhua Qingwen granules in treatment of COVID-19: A randomized controlled trial. Pharmacol. Res. 2020, 161, 105126. [CrossRef]

8. Lan, K.H.; Wang, Y.W.; Lee, W.P.; Lan, K.L.; Tseng, S.H.; Hung, L.R.; Yen, S.H.; Lin, H.C.; Lee, S.D. Multiple effects of Honokiol on the life cycle of hepatitis C virus. Liver Int. 2012, 32, 989-997. [CrossRef]

9. $\quad$ Fang, C.-Y.; Chen, S.-J.; Wu, H.-N.; Ping, Y.-H.; Lin, C.-Y.; Shiuan, D.; Chen, C.-L.; Lee, Y.-R.; Huang, K.-J. Honokiol, a lignan biphenol derived from the magnolia tree, inhibits dengue virus type 2 infection. Viruses 2015, 7, 4894-4910. [CrossRef] [PubMed]

10. Xu, T.; Tian, W.; Zhang, Q.; Liu, J.; Liu, Z.; Jin, J.; Guo, Y.; Bai, L.-P. Novel 1,3,4-thiadiazole/oxadiazole-linked honokiol derivatives suppress cancer via inducing PI3K/Akt/mTOR-dependent autophagy. Bioorganic Chem. 2021, 105257. [CrossRef]

11. Guo, Y.; Xu, T.; Bao, C.; Liu, Z.; Fan, J.; Yang, R.; Qin, S. Design and synthesis of new norfloxacin-1, 3, 4-oxadiazole hybrids as antibacterial agents against methicillin-resistant Staphylococcus aureus (MRSA). Eur. J. Pharm. Sci. 2019, 136, 104966. [CrossRef]

12. Rabie, A.M. Two antioxidant 2,5-disubstituted-1,3,4-oxadiazoles (CoViTris2020 and ChloViD2020): Successful repurposing against COVID-19 as the first potent multitarget anti-SARS-CoV-2 drugs. New J. Chem. 2021, 45, 761-771. [CrossRef]

13. Rabie, A.M. CoViTris2020 and ChloViD2020: A striking new hope in COVID-19 therapy. Mol. Divers. 2021, 25, 1839-1854. [CrossRef] [PubMed]

14. Rodon, J.; Muñoz-Basagoiti, J.; Perez-Zsolt, D.; Noguera-Julian, M.; Paredes, R.; Mateu, L.; Quiñones, C.; Perez, C.; Erkizia, I.; Blanco, I. Identification of plitidepsin as potent inhibitor of SARS-CoV-2-induced cytopathic effect after a drug repurposing screen. Front. Pharm. 2021, 12, 278. [CrossRef]

15. Nie, J.; Li, Q.; Wu, J.; Zhao, C.; Hao, H.; Liu, H.; Zhang, L.; Nie, L.; Qin, H.; Wang, M. Establishment and validation of a pseudovirus neutralization assay for SARS-CoV-2. Emerg. Microbes Infect. 2020, 9, 680-686. [CrossRef] [PubMed]

16. Yang, L.; Pei, R.; Li, H.; Ma, X.; Zhou, Y.; Zhu, F.; He, P.; Tang, W.; Zhang, Y.; Xiong, J. Identification of SARS-CoV-2 entry inhibitors among already approved drugs. Acta Pharmacol. Sin. 2020, 42, 1-7. [CrossRef]

17. Yu, J.; Li, Z.; He, X.; Gebre, M.S.; Dan, H.B. Deletion of the SARS-CoV-2 Spike Cytoplasmic Tail Increases Infectivity in Pseudovirus Neutralization Assays. J. Virol. 2021, 95, e00044-21. [CrossRef]

18. Li, H.; Zhao, C.; Zhang, Y.; Yuan, F.; Zheng, A. Establishment of replication-competent vesicular stomatitis virus-based recombinant viruses suitable for SARS-CoV-2 entry and neutralization assays. Emerg. Microbes Infect. 2020, 9, 1-24. [CrossRef] [PubMed]

19. Huang, S.W.; Tai, C.H.; Hsu, Y.M.; Cheng, D.; Wang, J.R. Assessing the application of a pseudovirus system for emerging SARS-CoV-2 and re-emerging avian influenza virus H5 subtypes in vaccine development. Biomed. J. 2020, 43, 375-387. [CrossRef]

20. Donofrio, G.; Franceschi, V.; Macchi, F.; Russo, L.; Missale, G. A Simplified SARS-CoV-2 Pseudovirus Neutralization Assay. Vaccines 2021, 9, 389. [CrossRef]

21. Lei, C.; Qian, K.; Li, T.; Zhang, S.; Hu, S. Neutralization of SARS-CoV-2 spike pseudotyped virus by recombinant ACE2-Ig. Nat. Commun. 2020, 11, 1-5. [CrossRef] [PubMed]

22. Chen, R.H.; Yang, L.J.; Hamdoun, S.; Chung, S.K.; Lam, C.W.; Zhang, K.X.; Guo, X.; Xia, C.; Law, B.Y.K.; Wong, V.K.W. 1,2,3,4,6-Pentagalloyl glucose, a RBD-ACE2 binding inhibitor to prevent SARS-CoV-2 infection. Front Pharm. $2021,12,150$.

23. Zhang, G.; Pomplun, S.; Loftis, A.R.; Loas, A.; Pentelute, B.L. The first-in-class peptide binder to the SARS-CoV-2 spike protein. BioRxiv 2020. Available online: https: / www.biorxiv.org/content/10.1101/2020.03.19.999318v1 (accessed on 16 August 2021).

24. Xu, T.; Zheng, Z.; Guo, Y.; Bai, L.-P. Semisynthesis of novel magnolol-based Mannich base derivatives that suppress cancer cells via inducing autophagy. Eur. J. Med. Chem. 2020, 205, 112663. [CrossRef] 
25. Vyas, B.; Choudhary, S.; Singh, P.K.; Singh, B.; Bahadur, R.; Malik, A.K.; Silakari, O. Identification of 2-benzoxazolinone derivatives as lead against molecular targets of diabetic complications. Chem. Biol. Drug Des. 2018, 92, 1981-1987. [CrossRef] [PubMed]

26. Ding, X.; Wu, Y.; Wang, Y.; Vilseck, J.Z.; Brooks, C.L., III. Accelerated CDOCKER with GPUs, Parallel Simulated Annealing, and Fast Fourier Transforms. J. Chem. Theory Comput. 2020, 16, 3910-3919. [CrossRef] [PubMed]

27. Towler, P.; Staker, B.; Prasad, S.G.; Menon, S.; Tang, J.; Parsons, T.; Ryan, D.; Fisher, M.; Williams, D.; Dales, N.A. ACE2 X-ray structures reveal a large hinge-bending motion important for inhibitor binding and catalysis. J. Biol. Chem. 2004, 279, 17996-18007. [CrossRef]

28. Yang, L.J.; Chen, R.H.; Hamdoun, S.; Coghi, P.; Ng, J.P.; Zhang, D.W.; Guo, X.; Xia, C.; Law, B.Y.K.; Wong, V.K.W. Corilagin prevents SARS-CoV-2 infection by targeting RBD-ACE2 binding. Phytomedicine 2021, 87, 153591. [CrossRef] [PubMed]

29. Wang, N.; Han, S.; Liu, R.; Meng, L.; He, H.; Zhang, Y.; Wang, C.; Lv, Y.; Wang, J.; Li, X. Chloroquine and hydroxychloroquine as ACE2 blockers to inhibit viropexis of 2019-nCoV Spike pseudotyped virus. Phytomedicine 2020, 79, 153333. [CrossRef] 